Canadian

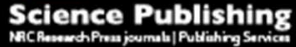

Canadian Journal of Earth Sciences Revue canadienne des sciences de la Terre

\title{
Borehole geophysical log signatures and stratigraphic assessment in a glacial basin, southern Ontario
}

\begin{tabular}{|c|c|}
\hline Journal: & Canadian Journal of Earth Sciences \\
\hline Manuscript ID & cjes-2017-0016.R1 \\
\hline Manuscript Type: & Article \\
\hline Date Submitted by the Author: & 26-May-2017 \\
\hline Complete List of Authors: & $\begin{array}{l}\text { Crow, Heather; Geological Survey of Canada, Natural Resources Canada } \\
\text { Hunter, James; Geological Survey of Canada, Natural Resources Canada } \\
\text { Olson, Laura; Geological Survey of Canada, Natural Resources Canada } \\
\text { Pugin, Andre; Geological Survey of Canada, Natural Resources Canada } \\
\text { Russell, Hazen; Geological Survey of Canada, Natural Resources Canada }\end{array}$ \\
\hline $\begin{array}{r}\text { Is the invited manuscript for } \\
\text { consideration in a Special } \\
\text { Issue? : }\end{array}$ & Quaternary Geology of Southern Ontario and Applications to \\
\hline Keyword: & $\begin{array}{l}\text { borehole geophysics, seismic velocity, stratigraphic interpretation, } \\
\text { glaciated terrains, southern Ontario }\end{array}$ \\
\hline
\end{tabular}


Borehole geophysical log signatures and stratigraphic assessment in a glacial basin,

4

Crow, Heather L.

Geological Survey of Canada, Natural Resources Canada 601 Booth Street, Ottawa, Ontario, Canada K1A OE8

Heather.Crow@Canada.ca

Hunter, James A.

Geological Survey of Canada, Natural Resources Canada 601 Booth Street, Ottawa, Ontario, Canada K1A OE8

Heather.Crow@Canada.ca

Olson, Laura C.

Geological Survey of Canada, Natural Resources Canada 601 Booth Street, Ottawa, Ontario, Canada K1A OE8

Laura.Olson@Canada.ca

Pugin, André J.-M.

Geological Survey of Canada, Natural Resources Canada 601 Booth Street, Ottawa, Ontario, Canada K1A OE8

André.Pugin@Canada.ca

Russell, Hazen A.J.

Geological Survey of Canada, Natural Resources Canada 601 Booth Street, Ottawa, Ontario, Canada K1A OE8

Hazen.Russell@Canada.ca

Corresponding author's contact information:

Heather Crow

Geological Survey of Canada, Natural Resources Canada 186-601 Booth Street, Ottawa, Ontario, Canada K1A OE8 Heather.Crow@Canada.ca

Tel.1- 613-992-2331

Fax not available. 
KEY WORDS - borehole geophysics, seismic velocity, stratigraphic interpretation, glaciated terrains, southern Ontario

\section{ABSTRACT}

Over the past two decades, the Geological Survey of Canada has used a standardized suite of slim-hole geophysical tools to log 57 PVC-cased boreholes drilled in the glacial sediments of southern Ontario. This article documents downhole tool responses (natural gamma, apparent conductivity, magnetic susceptibility, and seismic velocity) in the context of mineralogical characteristics of the region and grain size data from 28 of the 57 boreholes. Characteristic geophysical properties and/or patterns are identified within the units of a regional hydrostratigraphic framework in southern Ontario. The importance of a calibrated suite of tools is emphasized, as stratigraphic units may have variable response from site to site. The use of a high-sensitivity magnetic susceptibility induction probe is shown to be an important tool in the log suite for lithostratigraphic interpretation, and more broadly, for provenance studies of source rock across the region. Ranges of compressional $(\mathrm{P})$ and shear $(\mathrm{S})$ wave velocities and their ratios are provided for each of the hydrostratigraphic units. Case studies are presented to demonstrate how logs may assist in the interpretation of glacial processes at lithological boundaries. 


\section{Introduction}

Regional groundwater studies are often faced with limited data to resolve hydrostratigraphy and aquifer heterogeneity. Water well records are commonly the only widespread dataset available for hydrostratigraphic studies, but this information lacks geological resolution, integrity, and reliability (e.g., Russell et al. 1998). The most cost effective means to supplement the water well dataset is through applied geophysical techniques. Geophysical logs provide a continuous method to identify downhole variation in lithology based on changes in physical and chemical properties of sediments. Downhole geophysical logging (wireline logging) has a long history of applications in the petroleum industry (e.g., Cant, 1984) for characterization of basin stratigraphy, stratigraphic and formation correlation, characterization of scale and nature of reservoir heterogeneity, and estimation of reservoir properties. It has also been applied for over 35 years to similar problems in groundwater studies (e.g. Paillett et al., 1996; Keys, 1997; Paillett and Reese, 2000). Prior to the 1990's, geophysical logging was conducted using analogue tools, but manufacturers have since migrated to digital data collection and storage. This greatly enhances the value of the logging data, and offers an opportunity for quantitative (re)analysis, and integration of datasets for regional analyses. This increased level of interpretation, however, raises the significant issue of tool calibration and collection protocols.

Much of the groundwater research conducted in Canada is focused on glaciated basins within a glacial stratigraphy (e.g., Rivera, 2014). Interpretive knowledge gained from petroleum well logging studies has been in sedimentary bedrock environments where relatively slow rates of deposition are dominated by chemical weathering, rather than physical weathering and erosion 
87 (e.g. Hearst et al, 2000). Following two million years of glaciation during the Quaternary, northern North America has been largely denuded of chemically weathered bedrock (e.g., saprolite) by the Late Wisconsin. Rapid and voluminous deposition of glacial detritus common to many glacial settings (glaciofluvial, glaciolacustrine, ice-marginal) is accompanied by little time for mineralogical partitioning during formation of distinctly different horizons. Furthermore, glacial erosion produces a greater proportion of grains that are abraded to terminal mineral size. This has contributed to an abundance of "rock flour" (silt and clay-sized particles) dominated by the primary mineralogy of the provenance lithologies (e.g., quartz, feldspar, calcite) rather than by secondary alteration minerals (e.g., phyllosilicates). Consequently, there is an absence of mineralogical distinction between muds and the coarser grain size fraction, which can lead to challenges when interpreting variation in downhole stratigraphy using only one or two of the traditional geophysical logging techniques, such as natural gamma and electrical conductivity.

Over the past two decades, a standard suite of logs including natural gamma, apparent conductivity, magnetic susceptibility, and compressional (P) and shear $(\mathrm{S})$ wave velocities has been collected by the Geological Survey of Canada (GSC) in 226 cased wells across Canada (Crow et al., 2015a). In southern Ontario, 57 PVC-cased wells were sampled and geophysically logged (Figure 1). This dataset was collected using the same suite of tools, calibrated at the Bells Corners Borehole Calibration Facility in Ottawa, Ontario (Bernius, 1996; Mwenifumbo et al., 2005), and other sediment reference boreholes to ensure that the log suite provided consistent results over time. This unique dataset therefore allows for an interpretation of similarities and differences in depositional settings, chemistry, and provenance in locations across Canada. 
111 The primary objective of this article is to document the response of downhole geophysical tools 112 (gamma, conductivity, magnetic susceptibility, and velocity) in glacial sediments of southern 113 Ontario. The paper places the geophysical signatures within the context of known mineralogical 114 characteristics of the area and detailed grain size data available for 28 of the 57 logged holes. A 115 second objective is to relate patterns in the log responses to the range of depositional 116 environments present within the glaciated succession. The paper summarizes how the 117 characteristic geophysical properties and/or patterns can assist in placing glacial sediments 118 within the regional hydrostratigraphic framework.

\section{Geological Context of Southern Ontario.}

121 The $74,000 \mathrm{~km}^{2}$ of Southern Ontario in the Great Lakes basin is underlain by Paleozoic

122 sedimentary rocks that are overlain by up to $200 \mathrm{~m}$ of unconsolidated Quaternary sediment. The Niagara Escarpment, extending from Manitoulin Island southward into the United States, forms a major division between outcropping and subcropping Ordovician and Cambrian bedrock to the east, and Silurian and Devonian bedrock to the west. These sedimentary rock units are dominated by limestones and shales east of the escarpment, and dolomites, limestones and shales to the west. A background clay mineralogy signal is available from a limited suite of samples for outcropping and subcropping shale formations across southern Ontario (e.g. Martin and Kwong, 1986; Sadler, 1962; Béland Ottis, 2013). A broader literature does exist; however, results are commonly reported in a qualitative fashion (e.g., Guillet, 1977). Shale formation mineralogy generally consists predominantly of illite and chlorite minerals, with smaller amounts of vermiculite and inter-layered clays. For the formations presented in Martin and Kwong (1986) 
133

134

135

136

137

138

139

140

141

142

143

144

145

146

147

148

149

150

151

152

153

154

155

and Béland Otis (2013), clay minerals can be up to $55 \%$ of the rock mineralogy. Sadler (1962)

presents combined results of illite, chlorite, and feldspar of up to $77 \%$ for the Queenston Shale and $92 \%$ for the Dundas in Etobicoke, Toronto. Dolomite in bedrock is the principal constituent in the Silurian cap rocks of the Niagara Escarpment and westward (Armstrong and Carter, 2010).

To the north on the Canadian Shield, the Grenville province forms a mosaic of diverse metasedimentary and crystalline rocks grouped into two belts: the Central Metasedimentary Belt north of Lake Ontario, and the Central Gneiss Belt northeast of Georgian Bay. Saprolites can contain alteration minerals which produce elevated geophysical responses, but their extent for Late Wisconsin erosion are poorly constrained. Areas to the east in New Brunswick and Quebec, and to the west in Michigan and Minnesota have reported saprolites (e.g., Bouchard and Godard, 1985), but there are no such deposits documented for the hinterland of Southern Ontario. This suggests minimal saprolite occurrence as source rock potential for Late Wisconsin deposits in Southern Ontario.

The surficial deposits of Southern Ontario have a well-documented Late Quaternary succession of Illinoian, Sangamoian and Wisconsin sediment (e.g. Eyles and Williams, 1992). The pre-Late Wisconsin stratigraphy is most completely described from the Scarborough Bluffs, (Karrow, 1967), Toronto area (e.g., Karrow et al., 2001), Lake Erie Bluffs (Dreimanis, 1992) and other scattered locations across southwestern Ontario (e.g. Bajc et al., 2015). Fossil remains of the Sangamonian Don Valley Formation constrain underlying deposits to a likely Illinoian age and overlying deposits to early and Late Wisconsin (Scarborough, Thorncliffe formations and associated muddy diamictons). The Thorncliffe Formation is overlain by Newmarket Till, which 
156 157

is correlated with Catfish Creek Till to the southwest; these tills are considered to have been deposited during the Late Wisconsin maximum (e.g., Karrow, 1974). A succession of overlying Late Wisconsin deposits of glaciofluvial, glaciolacustrine stratified deposits and diamictons complete the glacial succession (e.g., Sharpe et al., 2002).

To facilitate data integration and regional 3D mapping across the Greater Toronto Area (GTA), a simplified regional stratigraphic framework was developed by Sharpe et al. (2002). With minor modifications, this framework is applicable to the Waterloo region (Table 1; Bajc et al. 2014). The bedrock surface forms the lower unconformity and is characterized by a range of valley scales containing a complex succession of glacial sediments (Gao, 2011; Russell et al., 2007). The Lower Sediments (also referred to as the lower deposits) is a grouping of ten pre-Late Wisconsin deposits that can be up to $150 \mathrm{~m}$ thick. West of the Niagara Escarpment, the lower sediments consist of glacial (e.g. Canning Till) and non-glacial deposits (e.g. Bajc et al., 2014). The sandy silt textured Newmarket Till and fine-textured, stone-poor facies of the Catfish Creek Till have been recognized regionally and are commonly characterized by a high velocity (e.g. Pullan et al., 2002; Bajc and Hunter, 2006). The surface of these tills is characterized by a drumlinized and channelized surface which forms a second regional unconformity (Sharpe et al. 2002; Bajc et al. 2014). Coincident with this undulating surface are tunnel channels that can be incised down to bedrock and host a range of fills depending upon location (e.g. Russell et al., 2003a, 2004). Where only partially infilled, knowledge of the fills is sparse, but near surface units are dominated by glaciolacustrine deposits and organics (e.g. north of the Oak Ridges Moraine). Where filled and buried by stratified moraines, the fill can consist of gravel, sand, and localized mud intervals (Russell et al, 2003a, Pugin et al. 1999). Areally extensive stratified 
moraines (Waterloo, Orangeville, Oro, and Oak Ridges) consist predominantly of sandy sediment with proximal gravel deposits and distal mud (e.g. Barnett et al 1998; Bajc et al., 2014; Sharpe et al. 2002). Sedimentary units are organized by an ice-confined depositional meltwater process of conduit flow, flow expansion, and proximal glaciolacustrine deposits (e.g. Russell and Arnott, 2003). Overlying and flanking the stratified moraines are a series of late-glacial, fine grained tills and younger glacial lacustrine deposits, which can contain sandy interbeds (e.g. Sharpe and Russell, 2016; Maclachlan and Eyles, 2011). This grouping of mud rich tills is attributed to multiple glacial lobes and includes approximately 17 tills mapped across southern Ontario by the Ontario Geological Survey (OGS) at 1:50,000 scale, as detailed by Barnett et al (1991).

Much of the chemical and mineralogical characterisation of Southern Ontario sediments has focused on tills (e.g. Dreimanis et al., 1957) with commensurately less attention on stratified sediments. Regional bedrock lithologies and weathering history impart a first order control on geochemistry. Carbonate content and calcite and dolomite percentage has been calculated expensively using Chittick apparatus since the early 1960s (Dreimanis, 1962). An extensive reference dataset exists for diamicton units as part of OGS surficial geological mapping and subsurface investigations (e.g. Karrow, 1987; Bajc and Shirota, 2007). Heavy mineral data is considerably less abundant but exists across the region for till units, and locally within core data (Bajc et al., 2015). An illustrative example is available in Karrow (1987) from the Hamilton to Cambridge area which describes a common suite of heavy minerals: magnetite-ilmenite, $8 \%$; hornblende, $47 \%$; clinopyroxene, $17 \%$; hypersthene, $3 \%$; white and purple garnet, $5 \%$; and red-orange garnet, $8 \%$. Elemental geochemistry data is available across southern Ontario (e.g. 
202

203

204

205

206

207

208

209

210

211

212

213

214

215

216

217

218

219

220

221

222

223

Sharpe et al., 2016) and in the GTA from core data (e.g. Knight et al., 2016) for the range of mapped surficial materials and subsurface stratigraphic units, respectively. Geotechnical studies in the Sarnia area have documented the clay mineralogy of glaciolacustrine deposits to range from approximately 21 to 45\% (Quigley and Ogunbadejo, 1973). This range of clay mineral concentrations is approximately one-half to one-third of that found in the shale units (see above).

\section{Data Distribution and geological setting}

A suite of downhole geophysical logs was collected in 57 continuously cored boreholes within three stratified moraines within Southern Ontario (Figure 1). Table 1 provides a generalized description of the key sediments found in the stratigraphic units, and identifies the formation names used in the different study areas.

\subsection{Greater Toronto area (GTA)}

Downhole data were collected in 29 boreholes ranging in depth from $18-187 \mathrm{~m}$ in the GTA (Figure 1). These boreholes were drilled predominantly in the Oak Ridges Moraine between 1993 and 2006, with an additional two boreholes near Wasaga Beach and two in South Simcoe County (Pullan et al., 2002; Crow et al., 2015a, Crow et al., 2015b). The dominant landform in the area is the Oak Ridges Moraine, a $160 \mathrm{~km}$-long ridge of sediment which forms the drainage divide between Georgian Bay and Lake Ontario. The stratigraphy of the GTA is Ordovician bedrock (limestone and shale) overlain by ten formations of the Lower Sediments. These formations of Illinoian to mid-Wisconsin age are primarily made up of sequences of silt-clay rhythmites and sand units, with minor sandy silt diamicton and muddy diamictons. These 
224 deposits are overlain conformably and unconformably by Newmarket Till, which is a regional 225 lithological and geophysical marker horizon. The top of Newmarket Till is both drumlinized and channelized and is, in turn, overlain by a range of late glacial $(<13,000 \mathrm{BP})$ sediments, most notably Oak Ridges Moraine, Halton formation (Sharpe and Russell, 2016), and glaciolacustrine deposits (e.g. Peel Ponds, lakes Schomberg and Algonquin).

\subsection{Oro Moraine}

In the region of the Oro Moraine, downhole logging was conducted in 2004-2005 in 14 boreholes ranging in depth from 20 - $116 \mathrm{~m}$ (Burt and Dodge, 2011). The moraine is underlain by Ordovician limestones although Precambrian gneisses of the Grenville Province outcrop a short distance to the north. A gravel lag and weathered bedrock overlie the limestone and form a basal aquifer. In the Oro area, the Lower Sediments consist of multiple units that are tentatively correlated with Scarborough and Thorncliffe stratigraphy and are overlain by Newmarket Till, which is commonly less than $20 \mathrm{~m}$ thick, drumlinized, and locally channelized. Sediments of the Oro Moraine $\left(165 \mathrm{~km}^{2}\right)$ unconformably overlie Newmarket Till and consist of sand and gravel units with some beds of silt to sand diamicton. The moraine was predominantly deposited in a series of ice-marginal environments as subaqueous fans, with evidence of esker conduits and occasional fine-textured glaciolacustrine sediments. The uppermost deposits found primarily west and north of the moraine are intersected in only two of the logged boreholes. A silty-clay aquitard underlies more permeable (sandy to gravely) postglacial to modern sediments deposited in Lake Algonquin (Burt and Dodge, 2011).

\subsection{Waterloo Moraine}

Borehole logging in the Waterloo moraine was completed in 2003-2004 in14 boreholes ranging in depth from 15 - $98 \mathrm{~m}$ (Bajc and Hunter, 2006). Bedrock in the area is Silurian-aged 
247 dolostone, shale, and evaporite (gypsum) bedrock. Overlying bedrock are a suite of units 248 referred to as pre-Canning glaciofluvial deposits and tills, Canning Till, and Pre-Catfish Creek 249 Till glaciofluvial deposits - all Lower Sediment equivalents. West of the Niagara Escarpment, 250 the Catfish Creek Till (Newmarket Till equivalent) is a regional sandy silt till sheet which can 251 252 (e.g., Dreimanis and Gibbard, 2005). The Waterloo Moraine unconformably overlies Catfish 253 Creek Till, and is a complex sequence of interbedded (gritty, pebbly) mud, sand, gravel, and

254 255 256 257

muddy diamicton. Surface tills (Port Stanley, Upper Maryhill, Tavistock, and Mornington) form a nearly continuous cover surrounding the moraine but become discontinuous over, and adjacent to, the moraine's centre (Bajc et al., 2014).

\section{Previous Borehole Geophysical Studies in Southern Ontario}

In the late 1970's and early 1980's, geophysical logging was first applied to the study of Quaternary stratigraphy in southern Ontario in the Laurentian Channel at sites south of Barrie by Sibul et al. (1977) and Fligg and Rodriguez (1983). In early days, drillers' logs were not sufficiently detailed to permit close comparisons between sediment descriptions and downhole geophysical logs, so a number of studies were undertaken to recover high quality cores to compare log responses with sediment textures in different regions throughout southern Ontario, east and west of the Niagara Escarpment (Eyles et al, 1985, Farvolden et al, 1987, Karrow et al, 1990; Greenhouse and Karrow, 1994; Schneider et al, 1994). In these studies, downhole logs identified geophysical marker horizons which could be used to interpret downhole variation in stratigraphy where core did not exist, and to correlate horizons from hole to hole within study areas. 
The Canadian development of a slim-hole induction (apparent conductivity) logging tool in the early 1980's (McNeill, 1980a; McNeil 1986) and subsequent industry evaluation (e.g. Taylor et al, 1989; McNeill et al., 1990) increased the range of logging applications available for use inside plastic-cased boreholes. When paired with a total count gamma sonde, this allowed geophysical logging to play an increasingly important role in groundwater investigations both in industry and academia, with studies ranging from glacial sediment stratigraphy to the investigation of contaminant impact on pore fluid conductivity. Subsequent development of an induction magnetic susceptibility logging tool proved to be highly useful for shallow lithological mapping where susceptibilities are typically low (McNeill et al., 1996).

As urban growth in regions north of Toronto increased demand on groundwater resources in the 1990's, studies of the Oak Ridges Moraine employed geophysical techniques (surface and downhole) to identify characteristic variations in material properties (e.g. high velocity tills) which could be used to identify geophysical marker horizons, and to map these units over large distances (e.g. Boyce et al, 1995; Pugin et al., 1999; Pullan et al, 2002; Gerrie et al, 2003). This work, along with continuously cored boreholes ("Golden Spikes”, e.g. Sharpe et al., 2003; Russell et al., 2003b, 2004; Logan et al., 2008; Sharpe et al., 2011) contributed to the development of a stratigraphic framework and 3D geological hydrostratigraphic model for the region (Sharpe et al 2004; Logan et al, 2005). The development of 3D models in numerous moraine settings in southern Ontario has been assisted by the use of geophysical logs in the correlation of stratigraphy (Bajc and Hunter, 2006; Bajc et al, 2014). 


\section{Gamma Methods}

Analytical approaches such as cross plotting of log responses, and more recently, principal component analyses have been used in identifying material type or grain size (Pehme, 1984; Karrow et al, 1990; Kassenaar, 1991; Pullan et al, 2002; Gerrie et al., 2003; Brennan, 2011). It has been recognized that a key requirement for these studies is a collection of calibrated geophysical logs (Gerrie et al, 2003; Crow et al, 2015a).

\section{Geophysical Logging Methods}

Geophysical logs recorded by the GSC in southern Ontario sediment boreholes between 1993 and 2013 include passive (natural) gamma, active gamma (relative density, spectral density ratio), induction (apparent conductivity and magnetic susceptibility), fluid temperature, and compressional wave velocities $(\mathrm{Vp})$ calculated from vertical seismic profiles. In many boreholes, shear wave velocities (Vs) were also calculated using horizontally polarized shear wave VSPs. Neutron logs were additionally collected by non-GSC personnel in 19 boreholes in the Waterloo (9), Oro (8), and GTA (2) study areas. All digital log data, along with logging procedures and systems, can be found in Crow et al. (2015a). In the present study, natural gamma, induction, and velocity ( $\mathrm{Vp}, \mathrm{Vs}) \operatorname{logs}$ were selected to characterize hydrostratigraphic unit responses as they were collected in nearly all the boreholes. These non-radioactive tools have a radius of investigation beyond the grout present in these holes and do not require specialized licenses, allowing for wider application within the hydrogeological community. 
315 Natural gamma (or gamma ray) logs measure naturally occurring radioactivity by converting gamma rays emitted from the formation into electronic pulses using a scintillator crystal in the tool, recorded in counts per second (cps). Scintillator crystals differ from probe to probe, resulting in differences in sensitivities between count levels; thus unless calibrated, a tool's counts represent relative changes in downhole lithology. The instrument used to collect all of the gamma log data presented here was Geonics Ltd.'s Gamma39 probe (with the exception of the two boreholes in the south Simcoe County area).

The most common natural radionuclides in rock and sediment are potassium (K), uranium (U), and thorium (Th). In total count logging, the number of cps are summed across the entire 3000 kiloelectron volt (keV) energy window. To gain insight into the contributions from the $\mathrm{K}$, U, and Th energy windows in each total count reading, a spectral gamma tool must be used. In these instruments, the amplitude of each received pulse over a given time interval is binned into energy windows to determine whether the gamma ray energy corresponds with the windows for $\mathrm{K}$, U, or Th. Although gamma rays from decaying isotopes of $\mathrm{K}$, and to a lesser extent, $\mathrm{U}$, and Th are present in the spectrum, the majority of the counts come from a lower energy band both in sediment and rock (Figure 2).

In southern Ontario where mineralogical composition of the sediments can be similar between muds and the coarser grain size fraction, often subtle changes in total count rates can be used in a qualitative manner to estimate changes in grain size, where $<2$ micron-sized grains exhibit higher count levels than the coarser grain size fraction. These trends are discussed in Section 6.0 where $\log$ response is examined alongside particle size analyses. 
$\underline{\text { Induction Methods }}$

The apparent conductivity logging tool (Geonics Ltd.'s EM39) uses an alternating $40 \mathrm{kHz}$ AC current in a dipole transmitter to generate a magnetic field which induces electric fields in the

343 formation. A dipole antenna receiver, in turn, measures the responding signal, which is proportional to the conductivity of the materials intersected by the borehole (McNeill et al., 1990). In studies of electrical conductivities in shales, clay minerals have a higher cation exchange capacity (CEC) due to water bound to the surface of the grains, and are therefore more conductive than coarser grained materials (Patchett, 1975; Hearst et al, 2000). Cation exchange capacity in soils and sediments increases with clay mineral content (McNeill, 1980b), hence although the percentage of clay minerals can be relatively low in the $<2$ micron fraction in the study areas, adsorbed ions on the surface of the $<2$ micron grains contribute to the increased conductivity, relative to the coarser grained silts and sands. In soil and bedrock logging, the mineral grains and pore water both contribute to the total (bulk) conductivity values measured. In the absence of conductive (saline, or leachate-impacted) pore water, the conductivity tool provides a method to identify lithological changes downhole associated with variation in mineralogy. The log generally follows the trends of the natural gamma log, where fine grained materials $(<2$ micron size) are more conductive than coarser grained materials.

The magnetic susceptibility logging tool (Geonics Ltd's EM39S) records the ratio between the primary magnetic field, and the in-phase component of the magnetic field caused by the presence of magnetically susceptible material in the formation. Although traditionally used for downhole 
361

362

363

364

365

366

367

368

369

370

371

372

373

374

375

376

377

378

379

380

381

382

383

mineral exploration due to its sensitivity to magnetic minerals (e.g. magnetite, pyrrhotite, ilmenite), the susceptibility tool is extremely useful for lithological logging in unconsolidated sediments of low susceptibilities (McNeill et al, 1996). This requires a very sensitive logging tool in the sub-parts-per-thousand (ppt) SI with a high degree of temperature compensation. Therefore, induction susceptibility loggers require a slightly different coil configuration than the apparent conductivity tools, with enhanced temperature compensation electronics. Due to the differing coil configurations between the EM39 and EM39S induction tools, the effective sphere of influence from the formation on the magnetic susceptibility response is approximately $0.5 \mathrm{~m}$ diameter, while the apparent conductivity is approximately $1.0 \mathrm{~m}$. In sediments derived from the Canadian Shield, we observe that the log response generally inversely mirrors the conductivity and gamma logs, as coarse grained materials have retained a higher percentage of heavier magnetic minerals than fine grained materials. In this setting, magnetic susceptibility also provides an indication of variation in sediment provenance, as the log responds positively $(5-$ $\left.20^{+} \mathrm{ppt} \mathrm{SI}\right)$ in sands and gravels derived from the Canadian Shield, but remains low $(1-4 \mathrm{ppt})$ in materials derived from carbonate and shale bedrock.

\section{$\underline{\text { Seismic Methods }}$}

Downhole compressional (Vp) wave and shear (Vs) wave velocities were calculated by measuring the traveltimes of waves propagating from a surface source to a series of downhole receivers. The entire wave train was recorded following the procedures described in Hunter et al. (1998), which allowed for the interpretation of later arriving events (e.g. reflections from horizons below the bottom of the borehole, converted waves, tube waves, etc.). P-wave logging 
384 was carried out in fluid-filled portions of the boreholes using a high-frequency in-hole surface 385 shotgun source with a 24-channel hydrophone array ( $0.5 \mathrm{~m}$ geophone spacings $)$ pulled up-hole at $3861 \mathrm{~m}$ intervals. Shear wave logging was carried out using a wall-locking instrument containing a 387 3-component geophone block, pulled up-hole at $1 \mathrm{~m}$ intervals. A loaded metal plate struck 388 389 390 horizontally with a sledgehammer was commonly used as a source. In addition to providing interval velocity characteristics of the sediments intersected by the borehole, downhole seismic data was used to correlate depths to reflections from surface seismic datasets. Shear waves are proving to be highly effective for lithological mapping of near-surface unconsolidated sediments, as slower velocities translate into shorter wavelengths, which have the potential to create higher resolution images of the subsurface. P-waves, although lower in resolution due to longer wavelengths, can penetrate more consolidated or coarser-grained sediments to image the underlying bedrock (e.g. Pugin et al., 2013a; Pugin et al., 2013b).

It is common to observe highly variable $\mathrm{Vp}$ and $\mathrm{Vs}$ in glacial tills, reflecting the poorly sorted, highly heterogeneous (chaotic) nature of the sediment deposition. $\mathrm{Vp}$ in unconsolidated materials are strongly affected by the velocity of the pore fluids, while Vs are transmitted through the material grains, making them much less sensitive to pore water composition, but 401 strongly influenced by overburden pressures and the degree of consolidation. Although much 402 more detail can be noted about velocities, the current discussion is limited to the Vp to Vs ratio. This ratio is a very useful indicator for depositional setting (i.e. lower ratios in glacially-loaded sediments versus higher ratios in deglacial valley-fill and glaciolacustrine environments; Hunter et al, 2007; Crow et al, 2015b). 


\section{Results}

Using the suite of geophysical tools presented here, log response within the glacial stratigraphy across southern Ontario can assist in placing logged intervals of boreholes within a hydrogeological context. As a first step, the correlations between grain size and geophysical tool response were examined, and from these observations, some characteristic geophysical properties and/or patterns within each stratigraphic unit have been described.

\subsection{Correlations between geophysical log response and grain size}

Datasets of weight percent (\%) sand (2 mm - 63 micron), silt (63-2 micron), and clay $(<2$ micron), are plotted alongside a suite of geophysical logs from a GTA borehole. Gamma and conductivity responses closely track the measured $<2$ micron size fraction, while the magnetic susceptibility log follows the sand content (Figure 3). At $2 \mathrm{~cm}$ recording intervals, the downhole logs allow for a more continuous qualitative interpretation of grain size variation than from grain size analyses (core sampling) alone. Instrument response to subtle changes in grain size (e.g. upward coarsening clay into silt, or silt into sand) provide important complementary information for studies of depositional processes and stratigraphic successions.

To examine these relationships of weight percent grain size versus log response, a few representative cross plots are presented from the logged interval (Figure 3). The evident scatter in the plots is primarily the result of the varied composition of the remaining grain size sample volume (i.e. a sample of $40 \%$ silt is also some combination of $60 \%$ sand and clay), but also the variability of material types sampled, the choice of sampling location in the cores, borehole conditions, and the vertical sonde resolution versus the thickness of the sediment layer sampled in the core. In addition, log response overlap, particularly with silt and sand, cautions an 
429 interpreter against making a quantitative assessment of sand-silt-clay distribution from the logs.

430 Despite these considerations, the plots indicate that conductivity response (and gamma, not 431 shown) is most strongly influenced by the presence of $<2$ micron-sized particles than silt or sand, 432 even though the sampled sediments do not contain more than $40 \%$ clay-size fraction by weight. 433 The correlation coefficient of $<2$ micron versus conductivity in this borehole is relatively high $(\rho$ $434=0.81 ; \rho=0.64$ for gamma). Silts do not appear to have a strong correlation with conductivity $435(\rho=0.28)$ and response tends to remain below $25 \mathrm{mS} / \mathrm{m}$ unless clay-sized particles are present in

436

437 438 439 440 441 442 443 444 445 446 447 448 449 450

amounts greater than $20 \%$ as indicated. In this borehole, the relationship between susceptibility and sand content is weakly positive $(\rho=0.51)$, as the sediments do not appear to contain elevated amounts of magnetic minerals (response range $1-10 \mathrm{ppt} \mathrm{SI}$ ).

Grain size analyses conducted by the OGS and GSC were available for 28 of the 57 geophysically logged boreholes: 9 from the Waterloo Moraine, 11 from the Oro Moraine, and 8 from the Oak Ridges Moraine. Regional cross plots show more scatter than for an individual borehole due to the larger dataset and wider geographic coverage, but the trends are similar (Figure 4). The plots primarily indicate that sediments sampled throughout the region rarely contain more than $40 \%<2$ micron size fraction by weight, but that gamma and conductivity responses are most strongly influenced by the presence of these particles. Regionally, gamma and conductivity responses to $<2$ micron content tend to be slightly more elevated west of the Niagara Escarpment than east. The magnetic susceptibility versus sand plot has a very low correlation value when examined as a regional dataset. When broken down by region, however, the plots reveal that magnetic susceptibility response is systematically lower west of the Niagara 
451

452

453

454

455

456

457

458

459

460

461

462

463

464

465

466

467

468

469

470

471

472

473

Escarpment than east, suggesting different mineralogical characteristics which should be examined independently.

Little mineralogical data exists for these cores at present, however, mineralogical variation strongly influences log response, and as shown in Figures 3 and 4, the magnetic susceptibility tool plays an important role within the suite. Intervals where magnetic susceptibility response is relatively low but where sand content is elevated suggests a non-igneous (Paleozoic) sand source. Regionally, the higher magnetic susceptibility response east of the Escarpment suggests an increased volume of magnetic mineral content from Canadian Shield-derived sand sediments. Additionally, response to $<2$ micron-sized grains from the Waterloo moraine area tend to be more conductive with higher gamma counts. This has been interpreted to indicate greater abundance of clay minerals in western sediments, however further mineralogical testing is required to confirm these relationships.

5

\subsection{Geophysical characteristics of the hydrostratigraphic units}

Grain size and mineralogical changes reflected in the geophysical logs have been used to identify patterns or characteristic intervals along a borehole. Variation in stiffness (density) of materials revealed from velocity measurements provide another important physical characteristic. Discussed below are common geophysical properties found within the broad hydrostratigraphic units encountered in southern Ontario (Table 1). Within each unit, representative geophysical logs are shown from the three study areas, and cross plots of grain size versus log response demonstrate characteristic responses. 
474 For the quantification of velocity ranges for each unit, basic statistical analyses were carried out. 475 Chauvenet's rejection standard error threshold was used to identify any statistical outliers based

476

477

478

479

480

481

482

483

484

485

486

487

488

489

490

491

492

493

494

495

496

on the number of data points in each unit. The data rejection threshold ranged from 2.98 to 3.63

standard deviations of the mean. Data outside the threshold were investigated and determined to be the result of traveltime picking errors or misplaced material boundaries. As a result, 18 velocity records out of 5114 were rejected (i.e. $0.35 \%$ of the data set). In boreholes where both $\mathrm{Vp}$ and $\mathrm{Vs}$ were collected, the ratio of $\mathrm{Vp}$ to $\mathrm{Vs}$ was calculated using this corrected dataset (Table 2). Of note in each of the units is the wide velocity distribution reflecting the natural variation in the sediments. In these glacial deposits, velocity distributions are often positively skewed, reflecting intervals of elevated velocity randomly present in the units (i.e. gravels, tills). This natural non-normal distribution tends to increase the standard deviation; therefore, one standard deviation is chosen to represent the velocity ranges.

\section{$\underline{\text { Lower Sediment }}$}

Seismic reflection profiles collected in the GTA in the 1990's have been interpreted to indicate that the Lower Sediments are composed of several units which are generally well stratified, horizontal, and laterally extensive. Based on correlations with borehole cores, geophysical logs and outcrops, interglacial formations (Scarborough and Thorncliffe) and diamictons (York, Sunnybrook) could be traced in the profiles over several kilometers (Pugin et al., 1999). In the oldest deposits of this unit, elevated velocities are the characteristic downhole responses in gravels and diamictons (York Till) above the bedrock. In the overlying sand and muds of the Scarborough and Thorncliffe formations, which are commonly interpreted to be delta, lacustrine, 
497 and subaqueous fans (e.g. Eyles et al., 1985; Sharpe et al. 2011), gamma and induction logs 498 produce a particularly distinct funnel-shaped pattern in the upward coarsening rhythmite 499 sequences as clay content decreases upward (Figure 5). This pattern is observed most 500 prominently east of the escarpment in the boreholes drilled in the GTA region (e.g. the Nobleton 501 borehole). Grain size versus log response plots within the Lower Sediment indicate a significant 502 degree of scatter, as it is composed of alternating (1) units, containing glaciolacustrine clays, 503 silts, and sands, and (2) silty-clay diamictons (Figure 6). Clay-sized particles have a strong 504 influence on gamma and conductivity log responses, and are present in quantities greater than in 505 the other hydrostratigraphic units. Magnetic susceptibility response is systematically lower $(<4$ 506 507

508 509 510 511 513 514 515 516

517 Within the high velocity till unit, composed of the Newmarket Till east of the escarpment and 518 Catfish Creek Till west of the escarpment, the lithological log responses (gamma, conductivity, 519 and magnetic susceptibility) indicate characteristically low and stable values, whereas $\mathrm{P}$ and $\mathrm{S}$ ppt SI) in the Waterloo region and does not increase with increasing sand content.

As a result of the many grain sizes and textural types (e.g. clays to gravels, laminated muds to tills) found in the Lower Sediment, velocity distributions are positively skewed due to the presence of high velocity diamictons and gravel intervals. Velocity logs in the lower sediment indicate that $\mathrm{Vp}$ and $\mathrm{Vs}$ are better discriminators of the tills than the lithological logs, but they must be greater than a few metres in thickness to be detected using the seismic techniques described herein.

$\underline{\text { High velocity tills }}$ 
wave velocities increase significantly, in relation to the surrounding sediment (Figure 7). The grain size versus log responses plot in tight clusters (Figure 8), as the matrix grain size of this unit is relatively homogeneous. The till is composed of approximately equal parts of silt and sand $(40-50 \%)$ with $<10 \%<2$ micron size, accounting for the relatively low gamma and conductivity responses. Even with the significant sand content, however, magnetic susceptibility has a relatively low response which forms another distinguishing feature of this unit. Recent GSC mineralogical studies from a core north of Oshawa, ON have found the Newmarket Till matrix assemblage to be composed of (in decreasing abundance) quartz, calcite, potassium feldspar, plagioclase, dolomite, amphibole, and clinopyroxene (Kjarsgaard et al. 2016) which accounts for the low response. Clasts larger than gravel-size were found to be limestone or granite, the latter may cause occasional spikes in magnetic susceptibility leading to some variability in this log relative to gamma and conductivity. If sand content increased relative to the underlying Lower Sediments, an abrupt increase in magnetic susceptibility was observed at that interface; however, the gamma, conductivity and magnetic susceptibility logs alone may not readily identify this unit from others in the sedimentary sequence. These observations corroborate earlier work by Pehme (1984) and Farvolden et al. (1987) in a study of geophysical responses in Catfish Creek Till.

The key geophysical signature of the typical Newmarket and Catfish Creek tills is the elevated P and $\mathrm{S}$ wave velocities (Table 2). Core measurements in a borehole north of Oshawa indicate the till density is similar to that of soft rock $\left(2.2-2.4 \mathrm{~g} / \mathrm{cm}^{3}\right)$, which could result from overconsolidation due to glacial loading, the presence of a secondary cement, or a combination of these processes (e.g. Kjarsgaard et al. 2016). The mean Vp of this unit is $20-30 \%$ greater than 
543 the other hydrostratigraphic units of the region, and similarly, the mean Vs is $15-45 \%$ higher. 544 The high density of the Catfish Creek Till has also been noted as a geophysical characteristic of 545 this unit by Farvolden et al. (1987). Based on seismic velocities, the two tills of this unit form a 546 regional marker horizon throughout southern Ontario.

547

548 A large standard deviation in the velocities of this marker unit led to a further examination of the 549 till east (Newmarket) and west (Catfish Creek) of the escarpment (Figure 9). Mean Vs in the 550 Catfish Creek till is $15 \%$ higher than the Newmarket Till, which suggests a slightly greater 551 552

563 The moraine and channel sediments are characterised by a highly variable magnetic 564 cementation-consolidation in the Catfish Creek Till. A comparison of Vp measured in high velocity tills intersected in 10 GTA boreholes and 9 Waterloo region boreholes indicates that the mean values are similar ( $\mathrm{Vp}$ is $5 \%$ higher in the Waterloo region). In the GTA, the thickness of the Newmarket Till ranges between $5.0-56.0 \mathrm{~m}$ with a mean thickness of $27.4 \pm 18.7 \mathrm{~m}$. In the Waterloo region, the range is halved in the Catfish Creek Till, measuring only $5.6-21.4 \mathrm{~m}$ with a mean of $15.2 \pm 6.6 \mathrm{~m}$. Vp values in the GTA boreholes have a broader range with a much larger standard deviation than in the Waterloo area boreholes. Thus despite the presence of a high velocity till sheet throughout much of southern Ontario, there are considerable local, regional, and stratigraphic variations observed within this unit.

\section{$\underline{\text { Moraine and channel deposits }}$} susceptibility log response (Figure 10), which commonly displays a slight upward increase in response through moraine deposits. This could indicate an upward coarsening, and/or could 
566 reflect a preferential sorting of Shield mineralogy. The gamma counts and conductivity levels 567 tend to remain low and unvarying due to limited $<2$ micron content (typically $<5 \%$ ). The rapid 568 vertical variation of the magnetic susceptibility signal reflects a more chaotic, high-energy style 569 of deposition with alternating coarse-to-fine grained deposits of gravels and sands; this is in 570 571 highly reflective, chaotic facies (Pugin et al, 1999).

572

573 The variable range of depositional conditions in this unit leads to elevated velocities in a few 574 gravel intervals, resulting in a relatively wide range in the Vp values. The mean Vp:Vs ratio is 575 lower than the overlying unit as the materials contain a greater percentage of sands and gravels 576 (Table 2).

577

$578 \quad \underline{\text { Surficial tills }}$

579

580 The late-glacial, $<2$ micron- and silt-rich surficial tills west of the Niagara Escarpment 581 characteristically exhibit elevated gamma (>100 cps) and conductivity $(>20-30 \mathrm{mS} / \mathrm{m})$ and low 582 magnetic susceptibility responses relative to the underlying moraine and channel sediments and high velocity tills. Although a representative example of geophysical log response in the GTA is not presented here due to near surface borehole completion effects, grain size plots show that the 585 surficial (Halton) tills intersected by the boreholes contain more silt, reducing the gamma and 586 conductivity responses (Figure 12). In the GTA, the tills are commonly intercalated with sandy sediment facies with decreased gamma and conductivity responses. The presence of $<2$ micron grain size strongly influences the gamma and conductivity response (Figure 12). These 
589 geophysical responses are also noted in the Waterloo region by Farvolden et al. (1987) and 590 Karrow et al. (1990), and more recently by Eyles et al. (2011) in gamma logs west of Toronto.

591

592

593

594

595

596

597

598

599

600

601

602

603

604

605

606

607

608

609

610

Grain size analyses from over 900 samples in the GTA in a study conducted by Sharpe and Russell (2016) show a clear distinction between the Halton Till, with a clayey-silt to silt matrix containing $1-2 \%$ stones, versus the Newmarket Till with a sandy-silt textured matrix and more stones (5-10\%). North of Hamilton, the Halton Till has been described as having a silt-rich matrix interstratified with silt and sand with a high shale content (Karrow, 1987).

While the $\mathrm{Vp}$ and Vs velocities tend to be low in the muddy diamictons, the Vp-to-Vs ratio is characteristically higher (mean of 4.0) than in the underlying sediments (mean of 3.5 or less, Table 2); this is due to reduced Vs with a lower degree of consolidation than the underlying materials.

\section{Discussion}

\subsection{Caveat: the need for multiple logs and mineralogical data in log interpretation}

Log signal response has long been interpreted within a scheme of geometric shapes and sedimentary facies analyses of depositional environments (e.g. Cant, 1984; Rider, 1990). Cant reviewed five geometries (cylindrical (blocky), bell, funnel, symmetrical, and irregular) commonly recognized from natural gamma logs. Such geometries are also common elements of 
611 conductivity/resistivity logs, and to a lesser extent, magnetic susceptibility logs. Cant suggests 612 these geometries can be considered as norms against which log signatures can be compared. 613 This type of analysis has also been applied to glacial sedimentary successions in Indiana (Bleuer, 614 2004). Rider (1990) highlighted the necessity for caution in making the assumption that the 615 gamma signal correlates with clay mineralogy, which in turn correlates to grain size and 616 subsequently to sedimentary facies (e.g. Bleuer, 2004). Rider noted that feldspars are equally 617 capable of influencing the gamma signal and thatfeldspars may not correlate well with the 618 assumed grain size relationships of higher gamma counts correlating to finer grain sizes. 619 Consequently, as conceptually attractive as it is to complete borehole geophysical analyses using 620 621 necessary.

622

A review of geophysical logs and corresponding grain size analyses from the Southern Ontario 624 datasets supports Rider's questioning of the robustness of this approach. Our experience 625 indicates that any geometric log analysis should only be completed by integration of gamma, 626 conductivity, and magnetic susceptibility logs, along with velocity (or density) $\operatorname{logs}$ (the latter 627 critical for the identification of the Catfish Creek and Newmarket Tills). Plots of weight percent 628 grain size versus log response indicate response of an individual log signal is not unique to a 629 630 unit may have variable signal depending upon the depositional setting(s) present within its 631 regional occurrence. Characterization thus requires integration of multiple geophysical logs for 632 interpretation of grain size trends, inference of depositional sedimentary facies, and possible 633 stratigraphic assignments. 
635 The suite of gamma and induction logs have responses that reflect changing grain size to varying

636

637

638

639

640

641

642

643

644

645

646

647

648

649

650

651

652

653

654

655

656

degrees, however, logs provide only a first order indication of changing mineralogy, both within

one borehole, and within a calibrated dataset across the region. In this respect, a high-sensitivity magnetic susceptibility probe is a key instrument to infer mineralogical change, but lab data are also needed to identify assemblages for provenance and depositional process studies. The paucity of subsurface geochemical information presents challenges for developing a robust interpretative framework for interpretation of the logging signals. Emerging data associated with the stratigraphic drilling programs of the Ontario Geological Survey (e.g. Bajc et al., 2015) and Geological Survey of Canada (e.g. Knight et al 2016) are gradually providing the data support for an enhanced geochemical characterization, and hence correlation with geophysical response. For example, the presence of abundant quartz and calcite in the Newmarket Till matrix accounts for the reduced variability and low response of the gamma and induction logs. By contrast, sands of similar grain size in moraine and channel deposits can produce more elevated magnetic susceptibilities. To date, knowledge from mostly near surface sampling indicates the Ontario portion of the Great Lakes basin is largely carbonate dominated, has low amounts of clay minerals, and has a secondary signal of Grenville Province geochemistry and mineralogy, dominated by quartz and minor amounts of feldspar.

The calibrated downhole dataset identified regional differences in log response between common stratigraphic units. In the Lower Sediment, log response versus grain size plots indicate that electrical conductivity and gamma response can be higher in $<2$ micron and silt grain sizes of the Waterloo region than in the Oro and GTA regions, hinting at the presence of a greater content of 
657 clay minerals. Conversely, the magnetic susceptibilities are systematically lower in Waterloo 658 Region Lower Sediment sand (1 - 3 ppt SI) than in the Oro and GTA regions $\left(3-20^{+}\right.$ppt SI). 659 This seems to indicate that the sands in the Waterloo area have a higher percentage of Paleozoic 660 relative to Shield-derived sediment and therefore have less magnetic mineral content. Also 661 noted in the borehole $\log$ suites from the three study areas are basal tills containing sands 662 exhibiting lower magnetic susceptibilities than sands from shallower depths, suggesting 663 664 when sand is present in significant percentages (e.g. 80-100\%).

665 666 667 668 669 670 1987).

671

More elevated gamma and conductivity responses in the silty-clay and clayey-silt surficial tills were also noted west of the Niagara Escarpment, relative to the east. In the future, mineralogical data (i.e. clay mineral content) could assist in the interpretation of these responses, as shale from the Queenston Formation has been a noted source material in the Hamilton region (Karrow,

\subsection{Implications for interpretation of glacial processes}

674 The response of geophysical $\operatorname{logs}$ at a stratigraphic boundary can provide key information in the 675 interpretation of glacial processes. At the boundary between the Newmarket Till and the Lower

676 Sediments, log responses in three boreholes across the GTA were examined (Figure 13).

677

In borehole $\mathrm{A}$, the transition at the boundary is sharp in all logs, reflecting a well sorted, fine 679 grained mud unit underlying a poorly sorted diamicton with a sandy silt matrix. The reverse 
response in the magnetic susceptibility data compared to the gamma and conductivity data confirms an increase in magnetic mineral content, reflective of the change from muds dominated by suspension sedimentation to the poorly sorted diamicton matrix that is deposited directly from the ice. The upward increase in Vp indicates a density increase within the diamicton. The sharp signal break across all logs suggests that the interface marks an unconformity, and that the depositing ice had integrated a minimal amount of the underlying material into the diamicton matrix. The cores examined below the contact show no evidence of deformation in the underlying laminated muds.

In borehole $\mathrm{B}$, the gamma log has no apparent change across the boundary with an upward increasing (fining) pattern having a slight decrease in amplitude within the diamicton unit. The conductivity log has a sharp drop across the contact but remains stable upward through the diamicton. The magnetic susceptibility and velocity logs increase sharply and stabilize above the boundary. The three lithological logs provide complementary information on the transition from Lower Sediment mud to diamicton; however the signal is not as clear and easily interpreted as (A). There is likely greater similarity in the matrix mineralogy in (B) than in (A). The gamma log suggests that mobilization or cannibalization of mud into the till is possible, but the change in induction logs support a strong contribution of unrelated and more Shield dominated mineralogy. The plateau in the magnetic susceptibility signal indicates that the increase is likely due to matrix mineralogy rather than oversized clasts.

In borehole $\mathrm{C}$, the three lithological log responses remain relatively low and smoothly varying across the boundary, with the indication of the Newmarket Till coming primarily from the 
703 increase in the P-wave velocity log. In this well, a different gamma tool was used for the logging 704 than in A and B, accounting for the more elevated cps. The logs suggest a gradational contact at 705 the base of the Newmarket Till which fines upward into a siltier matrix. Together, the logs 706 suggest a similar matrix material is present in both units, possibly through incorporation of the 707 underlying sediments. The low magnetic susceptibility log does not suggest Shield dominated 708 mineralogy is present in the matrix.

709

710

711

712

713

714

715

716

717

718

719

720

721

722

723

724

725

5

In these examples, the logs provide insight into the nature of the contact between the Lower Sediments and the Newmarket Till. The gamma and induction logs indicate whether the boundary is abrupt or more continuous in nature, from which an interpretation on glacial processes at that location can be made. An examination of this boundary in the borehole dataset indicates that conditions were not uniform across the basin.

\subsection{Application of geophysical logs within hydrogeology studies}

To advance groundwater understanding requires increased collection of reliable data. The era for reliance on water well records is long past, given the range of data quality and resolution issues (e.g. Russell et al., 1998). Increasing conflict in land use issues and stress on surface and subsurface resources requires increased integration of high quality data in groundwater modelling and decision-making. The need for such a change in data support has been recognized for over 20 years (e.g., Bhatt, 1993) yet both modelling and consequently management decisions continue to be based on inadequate data quality and data support. The use of a regional framework for interpreting downhole geophysical logs presents another cost effective manner of adding hydrostratigraphic context to a borehole dataset. 
727 Currently, a lack of borehole calibration sites has limited the ability of consultants to collect data

728

729

730

731

732

733

734

735

736

737

738

739

740

741

742

743

744

745

746

747

to a common standard. A requirement by contracting authorities (conservation authorities, municipal and provincial governments) to insist on data collection following a standard calibration protocol would enable data to be normalized for specific tools; hence, individual studies could be more broadly used by the groundwater community. The issue of calibration has been addressed in other jurisdictions with similar geology to Southern Ontario, such as Denmark. A national borehole calibration facility operated by the GSC near Ottawa is freely available for public use, but boreholes do not intersect glacial sediments and the facility is distant from the GTA. A recent leadership example in southern Ontario is the University of Guelph's bedrock aquifer field facility (BAFF) where boreholes intersecting bedrock and glacial sediments are being used to teach and train professional staff in applied groundwater research.

\section{Summary}

Over the past three decades, a suite of geophysical logs has been collected by the GSC in 57 PVC-cased wells drilled in the glacial sediments of southern Ontario. Rapid deposition of many of these sedimentary units has resulted in reduced time for mineralogical partitioning and associated mineralogical contrast between bedding horizons. Sand, silt and clay-sized grains are dominated by the primary mineralogy (e.g., quartz, feldspar, calcite) of the provenance lithologies (crystalline rocks, limestones) rather than by secondary alteration minerals (e.g., phyllosilicates). Consequently, when the weight percent $<2$ micron grain size fraction is low (approximately $<20 \%$ ), there can be an absence of mineralogical distinction between the sediments, resulting in a reduced range of downhole log responses. This often causes $\log$ 
748 749 750 751 752 753 754 755 756 757

overlap for different grain size distributions when only one or two of the conventional lithological logging tools are used (e.g. gamma, conductivity).

As a result, integration of a wider suite of tools (gamma, conductivity, magnetic susceptibility, and velocity logs) becomes important in distinguishing patterns in hydrostratigraphic sequences. The use of a high-sensitivity magnetic susceptibility induction probe in the log suite is found to be an important tool for lithostratigraphic interpretation, and more broadly, for provenance studies of source rock across the region. Ongoing studies of sediment mineralogy are helping to better understand tool response, such as in the Newmarket Till.

For each of the hydrostratigraphic units, the ranges of P- and S-wave velocities, and Vp:Vs ratios have been provided. Although there is overlap in the velocity ranges found within the units, Pand S-wave velocities are necessary in the log suite to identify Newmarket and Catfish Creek tills which form a key geophysical marker horizon across the region. Vp logs in the Newmarket till indicate that where the unit is thick (i.e. $>20 \mathrm{~m}$ ), a broader range of velocities exist than where it is thin, suggesting that conditions during deposition were not uniform, despite the presence of a high velocity till sheet throughout much of southern Ontario. Velocity profiles also identify the presence of gravel units or basal tills which are otherwise difficult to detect with lithological logging tools alone. In addition to hydrogeological studies, Vs is also an important geotechnical parameter used to predict regional variation in earthquake shaking, making these velocity ranges and ratios valuable for other disciplines (e.g. engineering, geohazards) in this highly populated region of Canada. 
771 Although water well records are commonly available for hydrogeological studies, these data 772 generally lack the geological resolution and reliability of digital geophysical logs, which allow 773 for quantitative (re)analysis of stratigraphy and marker horizons. It is anticipated that a 774 framework for the interpretation of geophysical logs in southern Ontario will offer a cost775 effective method for placing boreholes within a hydrostratigraphic context. This, however, 776 raises the issue of tool calibration and collection protocols for the future standardization of these 777 logs, which will present itself as an important next step for incorporation of geophysical data into 778 large regional analyses for the hydrogeological community.

\section{Acknowledgments}

781

782

783

We wish to recognize the technique development and dataset collection of R. Good, R. Burns, S. Pullan, M. Douma, T. Cartwright, and K. Brewer. The collaboration with the Ontario Geological Survey and A. Bajc and A. Burt for the drilling of boreholes and sharing of stratigraphic logs and grain size datasets was particularly appreciated. We sincerely appreciate the insights and resulting improvements from comments by anonymous journal reviewers and the guest editor. This work was carried out at GSC-Ottawa under the Aquifer Assessments and Support to Mapping Groundwater Inventory Project of the Groundwater Geoscience Program. This work is a contribution of the GSC-OGS Southern Ontario project on groundwater 2014-2019 (NRCan Contribution 20170073).

\section{References}

Armstrong, D.K., Carter, T.R., 2010. The subsurface Paleozoic stratigraphy of southern Ontario. Ontario Geological Survey, Special Volume 7. 
793

794

795

796

797

798

799

800

801

802

803

804

805

806

807

808

809

810

811

Bajc AF, and Hunter JA, 2006. Results of 2003-2004 overburden drilling programs in the Region of Waterloo, southwestern Ontario. Miscellaneous Release-Data 205. Sudbury, ON: Ontario Geological Survey.

Bajc AF, and Shirota J, 2007. Three-dimensional mapping of surficial deposits in the Regional Municipality of Waterloo, southwestern Ontario; Ontario Geological Survey. Groundwater Resources Study 3.

Bajc AF, Russell HAJ, and Sharpe DR. 2014. A three-dimensional hydrostratigraphic model of the Waterloo Moraine area, southern Ontario, Canada, Canadian Water Resources Journal http://dx.doi.org/10.1080/07011784.2014.914794

Bajc, A.F., Mulligan, R.P.M., Rainsford, D.R.B., Webb, J.L., 2015. Results of 2011-13 overburden drilling programs in the southern part of the County of Simcoe, south-central Ontario. Ontario Geological Survey. Misc. Release-Data 324.

Barnett, P.J., Henry, A.P., and Cowan, W.R. 1991. Quaternary geology of Ontario, southern sheet. Ontario Geological Survey, Map 2556, scale 1:1 000000.

Barnett, P.., Sharpe, D.., Russell, H.A.J., Brennand, T.A., Gorrell, G., Kenny, F., and Pugin, A.JM., 1998. On the origin of the Oak Ridges Moraine. Can. J. Earth Sci. 35, 1152-1167. doi:10.1139/cjes-35-10-1152

Béland Otis, C. 2013. Gas assessment of the Devonian Kettle Point Formation; Ontario Geological Survey, Open File Report 6279, 63 p 
812 Bernius, G.R; 1996. Borehole geophysical logs from the GSC Borehole Geophysics Test Site at 813 Bell's Corners, Nepean, Ontario, Geological Survey of Canada, Open File 3157, 1996; 38 pages, doi:10.4095/207617

815

816

817

818

819

820

821

822

823

824

825

826

827

828

829

830

Bhatt K, 1993. Uncertainty in wellhead protection area delineation due to uncertainty in aquifer parameter values. J. Hydrol. 149, 1-8.

Bleuer, N. K. 2004, Slow-logging subtle sequences the gamma-ray log character of glacigenic and other unconsolidated sedimentary sequences: Indiana Geological Survey Special Report 65, 39 p., 27 fig.

Boyce J.I, Eyles N.E, and Pugin AJ-M, 1995. Seismic reflection, borehole and outcrop geometry of Late Wisconsin tills at a proposed landfill near Toronto, Ontario, Can. J. Earth Sci., 32: $1331-1349$

Bouchard, M., Godard, A., 1985. Les altérités du bouclier canadien: premier bilan d'une campagne de reconnaissance. Geographique Physique et Quaternaire. 38, 149-163.

Brennan AN, 2011. Characterizing the Quaternary hydrostratigraaphy of buried valleys using multi-parameter borehole geophysics, Georgetown, Ontario. Unpublished MSc thesis, McMaster University, London, Ontario

Burt, A.K. and Dodge, J.E.P. 2011. Three-dimensional modelling of surficial deposits in the Barrie-Oro Moraine area of southern Ontario; Ontario Geological Survey, Groundwater Resources Study 11. 
831

832

833

834

835

836

837

838

839

840

841

842

843

844

845

846

847

848

849

850

Cant, D.J., 1984. Subsurface Facies Analysis, in: Facies Models. Geological Association of Canada, pp. 297-310.

Coffin LM, Knight RD, Popovic N, Prowse ND, Russell HAJ, 2017. Sedimentology and geochemistry of the Purple Woods borehole, southern Ontario; Geological Survey of Canada, Open File 7899, 2017; 1 sheet, doi:10.4095/299433

Crow HL, Good RL, Hunter JA, Burns RA, Reman A, and Russell HAJ, 2015a. Borehole geophysical logs in unconsolidated sediments across Canada. Geological Survey of Canada, Open File 7591, 39 pages, doi:10.4095/295753

Crow HL, Brewer KD, Bajc AF, Pugin AJ -M, Mulligan RPM, and Russell HAJ, 2015 b. Downhole geophysical data from two boreholes in the south Simcoe County, Ontario. Geological Survey of Canada, Open File 7883, 18 pages (2 sheets), doi:10.4095/296884

Dreimanis, A, 1962. Quantitative gasometric determination of calcite and dolomite by using Chittick apparatus, Journal of Sedimentary Petrology, v.32, p.520-529.

Dreimanis, A., 1992. Early Wisconsinan in the north-central part of the Lake Erie basin: A new interpretation. Geol. Soc. Am. Spec. Pap. vol. 270 109-118.

Dreimanis, A., Gibbard, P.L., 2005. Stratigraphy and sedimentation of the stratotype sections of the Catfish Creek Drift Formation between Bradtville and Plum Point, north shore, Lake Erie, southwestern Ontario, Canada. Boreas 34, 101-122.

Dreimanis, A., Reavely, G.H., Cook, R.J.B., Knox, K.S., Moretti, F.J., 1957. Heavy mineral studies of tills of Ontario and adjacent areas. J. Sediment. Petrol. 27, 148-161. 
851

852

853

854

855

856

857

858

859

860

861

862

863

864

865

866

867

868

869

870

871

Eyles, N. and Williams, N.E.1992. The sedimentary and biological record of the last interglacial glacial transition at Toronto, Canada. Geological Society of America Special Papers, vol. 270, p. 119-138.

Eyles N, Eyles C, Menzies J, Boyce J. 2011. End moraine construction by incremental till deposition below the Laurentide Ice Sheet: Southern Ontario, Canada. Boreas, Vol. 40, pp. 92-104. 10.1111/j.1502-3885.2010.00171.x. ISSN 0300-9483.

Eyles NE, Clark BM, Kaye BG, Howard KWF, and Eyles CH, 1985. The application of basin analysis techniques to glaciated terrains: an example from the Lake Ontario Basin, Canada. Geoscience Canada 12:1, 22 - 32

Farvolden RN, Greenhouse JP, Karrow PF, Pehme PE, and Ross LC, 1987. Ontario Geoscience Research Grant Program, Grant No. 128, Subsurface Quaternary stratigraphy of the Kitchener-Waterloo area using borehole geophysics; Ontario Geological Survey, Open File Report 5623, 76p

Fligg, K, Rodriguez, B, 1983. Geophysical well log correlations between Barrie and the Oak Ridges Moraine; Water Resources Branch, Ontario Ministry of the Environment, Map 2273.

Gao C, 2011. Buried bedrock valleys and glacial and subglacial meltwater erosion in southern Ontario, Canada; Can. J. Earth Sci. 48: 801-818

Gerrie V, Holysh S, Boyce J, Pullan SE, Blasco K, and Collins S, 2003. Borehole geophysics and its potential for mapping the geological framework of the Oak Ridges Moraine, southern Ontario; in proceedings of the 56th Canadian Geotechnical Conference and the 4th Joint IAHCNC/CGS Conference, Winnipeg, Manitoba, Canada, September 29-October 1, 2003 
872 Greenhouse JP, and Karrow PF, 1994. Geological and geophysical studies of buried valleys and 873 their fills near Elora and Rockwood, Ontario; Can. J. Earth Sci., 31; 1838-1848

874 Guillet, JR, 1977. Clay and shale deposits of Ontario: Ontario Geological Survey Mineral 875 Deposits Circular, MDR 15, Ministry of Natural Resources

876

877

878

879

880

881

882

883

884

885

886

887

888

889

Hearst JR, Nelson PH, and Paillett FL, 2000. Well logging for physical properties. New York, NY: John Wiley and Sons Inc.

Hunter JA, 2007. Measurements of compressional and shear wave velocities and formation porosities in Quaternary sediments; in proceedings of the $60^{\text {th }}$ Canadian Geotechnical Conference (GeoOttawa), October 21 - 24, 2007, 491-498

Hunter JA, Pullan SE, Burns RA, Good RL, Harris JB, Pugin AJ-M, Skvortsov A, and Gorianov NN, 1998. Downhole seismic logging for high-resolution reflection surveying in unconsolidated overburden. Geophysics 63:4, 1371-1384

Karrow, P.F., 1967. Pleistocene Geology of the Scarborough Area. Ontario Ministry of Natural Resources. Toronto, Report 46,108 p.

Karrow, PF, 1974. Till stratigraphy in parts of southern Ontario, Geological Society of America Bulletin, v 85, p 761-768

Karrow, P.F. 1987. Quaternary geology of the Hamilton-Cambridge area, southern Ontario. Ontario Geological Survey, Report 25, 94 pp. 
890

891

892

893

894

895

896

897

898

899

900

901

902

903

904

905

906

907

908

Karrow PF, Greenhouse JP, and Dusseault MB, 1990. Ontario Geoscience Research Grant Program, Grant No. 312, Subsurface Quaternary using borehole geophysics; Ontario Geological Survey, Open File Report 5734, 249p

Karrow, P.F., McAndrews, J.H., Miller, B.B., Morgan, A. V, Seymour, K.L., White, O.L., 2001. Illinoian to Late Wisconsinan stratigraphy at Woodbridge, Ontario. Can. J. Earth Sci. 38, 921-942. doi:10.1139/e00-108

Kassenaar, JDC, 1991. An application of principal component analysis to borehole geophysical data; in proceedings of the $4^{\text {th }}$ International MGLS/KEGS Sympisium on Borehole Geophysics for Minerals, Geotechnical ad Groundwater Applications; Toronto, 18-22 August 1991.

Keys S, 1997. A practical guide to borehole geophysics in environmental investigations; Boca Raton, Florida, CRC Press Inc.

Kjarsgaard, B., Knight, R.D., Russell, H.A.J., Sharpe, D.R., Crow, H., Olson, L., 2016. Newmarket Till Aquitard: Optimum Grain Packing, With A Pore Filling Cement Generates Pseudo-Concrete, in: Geological Society of America Abstracts with Programs. Vol. 48, No. 7. doi:10.1130/abs/2016AM-285066

Knight, R.D., Valiquette, L.J., and Russell, H.A.J. 2016. Portable XRF spectrometry, fusion, multi acid, and aqua regia results from the Queensville borehole, Yonge Street Aquifer, southern Ontario. Geological Survey of Canada, Open File 7855, 23 pages. 
909 910 911 912 913 914 915 916 917 918 919 920 921

Logan C, Russell HAJ, and Sharpe DR, 2005. Regional 3-D structural model of the Oak Ridges Moraine and Greater Toronto area, southern Ontario: version 2.1, Geological Survey of Canada, Open File 5062; 27 pages; 1 CD-ROM, doi:10.4095/221490

Logan CE, Knight RD, Crow HL, Russell HAJ, Sharpe DR, Pullan SE, and Hinton MJ, 2008. Southern Ontario “Golden Spike: data release: Nobleton borehole; Geological Survey of Canada, Open File 5809; 29 pages; 1 CD-ROM, doi:10.4095/225026

Maclachlan, J.C., Eyles, C.H., 2011. Subglacial deforming bed conditions recorded by late Quaternary sediments exposed in Vineland Quarry, Ontario, Canada. Sediment. Geol. 238, 277-287. doi:10.1016/j.sedgeo.2011.04.016

Martin, P.I. and Kwong, J.K.P. 1986. Geology and Ceramic Properties of Selected Shales and Clays of Southwestern Ontario; Ontario Geological Survey, Open File Report 5583

McNeill JD, 1980a. Electromagnetic terrain conductivity measurement at low induction numbers; Geonics Limited Technical Note TN-6.

McNeill JD, 1980b. Electrical Conductivity of Soils and Rocks; Geonics Limited Technical Note TN-5.

McNeill JD, 1986. Geonics EM39 Borehole conductivity meter - Theory of operation; Geonics Limited Technical Note TN-20.

McNeill JD, Bosnar M, Snelgrove FB, 1990. Resolution of an electromagnetic borehole conductivity logger for geotechnical and ground water applications; Geonics Technical Note TN-25 
929

930

931

932

933

934

935

936

937

938

939

940

941

942

943

944

945

946

947

McNeill JD, Hunter JA, Bosnar M, 1996. Application of a borehole induction susceptibility logger to shallow lithological mapping, J. Environmental and Engineering Geophysics, 0:2, p. 77-90.

Mwenifumbo, C J; Elliott, B E; Hyatt, W G; Bernius, G R; 2005. Bells Corners calibration facilities for downhole and surface geophysical equipment Geological Survey of Canada, Open File 4838, 2005; 17 pages, doi:10.4095/216755

Paillett FL, Crowder RE, 1996. A Generalized Approach for the Interpretation of Geophysical Well Logs in Ground-Water Studies-Theory and Application. Ground Water 34, 883-898. doi:10.1111/j.1745-6584.1996.tb02083.x

Paillett FL, Reese RS, 2000. Integrating Borehole Logs and Aquifer Tests in Aquifer Characterization. Ground Water 38, 713-725. doi:10.1111/j.1745-6584.2000.tb02707.x

Patchett J, 1975. An investigation of shale conductivity, Log Analyst, 16:6, p.3

Pehme PE, 1984. Identification of Quaternary deposits with borehole geophysics in the Waterloo Region, Unpublished MSc thesis, University of Waterloo, Waterloo, Ontario, 124p.

Pugin AJ-M, Pullan SE, and Sharpe DR, 1999. Seismic facies and regional architecture of the Oak Ridges Moraine area, southern Ontario, Can. J. Earth Sci. 36, 409-432

Pugin AJ -M, Pullan SE, Duchesne M, 2013a. Regional hydrostratigraphy and insights into fluid flow through a clay aquitard from shallow seismic reflection data; The Leading Edge, Special Section: Hydrogeophysics, p. 936-942. 
948 Pugin AJ -M, Brewer K, Cartwright T, Pullan SE, Perret D, Crow H, Hunter JA, 2013b. Near 949 surface S-wave seismic reflection profiling - new approaches and insights; First Break vol. 31, 2013; p. 49-60

951 952 953 954 955 956 957 958 959 960 961 962 963 964 965 966 967 968

Pullan SE, Hunter JA, and Good RL, 2002. Using downhole geophysical logs to provide detailed lithological and stratigraphic assignment, Oak Ridges Moraine, southern Ontario; Geological Survey of Canada, Current Research (Online) no. 2002-E8, 2002; 12 pages, doi: $10.4095 / 213689$

Quigley, R.M., Ogunbadejo, T.A., 1973. Till Geology, Mineralogy and Geotechnical Behaviour, Sarnia, Ontario, in: Leggett, R.F. (Ed.), Glacial Till. Royal Canadian Society Special Publication, pp. 336-346.

Rider, M.H, 1990. Gamma-ray log shape used as a facies indicator: critical analysis of an oversimplified methodology, in: Hurst, A., Lovell, M.A., Morton, A.C. (Eds.), Geological Applications of Wireline Logs Geological Society Special Publication No. 48. Geological Society of London, London, pp. 27-37.

Rivera, A., 2014. Canada's Groundwater Resources. Fitzhenry \& Whiteside Limited, Markham.

Russell, H.A.J., Arnott, R.W.C., 2003. Hydraulic-Jump and Hyperconcentrated-Flow Deposits of a Glacigenic Subaqueous Fan: Oak Ridges Moraine, Southern Ontario, Canada. J. Sediment. Res. 73, 887-905. doi:10.1306/041103730887

Russell HAJ, Sharpe DR, Hunter JA, 2004. Pontypool "Golden Spike” borehole digital data compilation: sedimentology and geophysical data; Geological Survey of Canada, Open File 4540, 2004; 1 CD-ROM, doi:10.4095/214994 
969

970

971

972

973

974

975

976

977

978

979

980

981

982

983

984

985

986

987

Russell, H.A.J., Sharpe, D.R., Cummings, D.I., 2007. A framework for buried-valley aquifers in southern Ontario, in: Proceedings of the 60th Annual Canadian Geotechnical Society (CGS) and 8th Joint Canadian National Chapter of the International Association of Hydrogeologists (IAH-CNC) Groundwater Specialty Conference. Canadian Geotechnical Society and International Association Hydrogeologists, pp. 386-393.

Russell, H.A.J., Brennand, T.A., Logan, C., Sharpe, D.R., 1998. Standardization and assessment of geological descriptions from water well records, Greater Toronto and Oak Ridges Moraine areas, southern Ontario. Geol. Surv. Canada, Curr. Res., Current research 1998-E 1998-E, 89-102.

Russell HAJ, Sharpe DR, Brennand TA, Barnett PJ, and Logan C, 2003a. Tunnel channels of the Greater Toronto and Oak Ridges Moraine areas, southern Ontario; Geological Survey of Canada, Open File 4485; 1 sheet, doi:10.4095/214777

Russell HAJ, Peets J, Gorrell G, Sharpe DR, and Hunter JA, 2003b. Pontypool "Golden Spike” borehole data compilation, Geological Survey of Canada, Open File 1746; 1 sheet, doi:10.4095/214401

Sadler, A.G., 1962. The Mineral Constitution Of Some Ordovician Shales Of Eastern And Southern Ontario. Dep. Mines Tech. Surv. Ottawa, Mines Branch Res. Rep. R 94.

Schneider GW, Nobes DC, Lockhard MA, and Greenhouse JP. 1994. Urban geophysics in the Kitchener-Waterloo region; Geoscience Canada, 20: 149 - 156 
988 989 990 991 992 993 994 995 996 997 998 999

Sharpe, D.R., Russell, H.A.J., 2016. A revised depositional setting for Halton sediments in the Oak Ridges Moraine area, Ontario. Can. J. Earth Sci. 53, 281-303. doi:10.1139/cjes-20150150

Sharpe DR, Pullan SE, and Gorrell G, 2011. Geology of the Aurora high-quality reference site and significance to the Yonge Street buried valley aquifer, Ontario; Geological Survey of Canada, Current Research (Online) no. 2011-1; 24 pages, doi:10.4095/286269

Sharpe, D.R., Hinton, M.J., Russell, H.A.J., and Desbarats, A.J., 2002. The need for basin analysis in regional hydrogeological studies: Oak Ridges Moraine, southern Ontario. Geoscience Canada 29, 3-20.

Sharpe DR, Pugin AJ-M, Pullan, SE, and Shaw, J, 2004. Regional unconformities and the sedimentary architecture of the Oak Ridges Moraine area, southern Ontario, Can J. Earth Sci., 41: $183-198$

Sharpe, D.R., Klassen, R.A., Russell, H.A.J., Logan, C.L., and Garrett, R. 2016. Regional geochemical survey of soil and sediment in southern Ontario; in Russell H.A.J. and Priebe, E. (editors) Regional-scale groundwater geoscience in southern Ontario: an Ontario Geological Survey and Geological Survey of Canada groundwater geoscience open house; Geological Survey of Canada, Open File 8022, 17 pages

Sharpe DR, Dyke LD, Good RL, Gorrell G, Hinton MJ, Hunter JA, Russell HAJ, 2003. GSC high-quality borehole "Golden Spike" data - Oak Ridges Moraine, southern Ontario; Geological Survey of Canada, Open File 1670; 23 pages, doi:10.4095/214289 
1008 Sibul U, Wang KT, and Vallery D, 1977. Ground-water resources of the Duffins Creek-Rouge 1009 River Drainage Basins; Ministry of the Environment, Water Resources Branch; Water $1010 \quad$ Resources Report 8.

1011 Taylor KC, Hess JW, and Mazzela A, 1989. Field evaluation of a slim-hole borehole induction 1012 tool, Groundwater Monitoring Review, 9:1; 100-104 


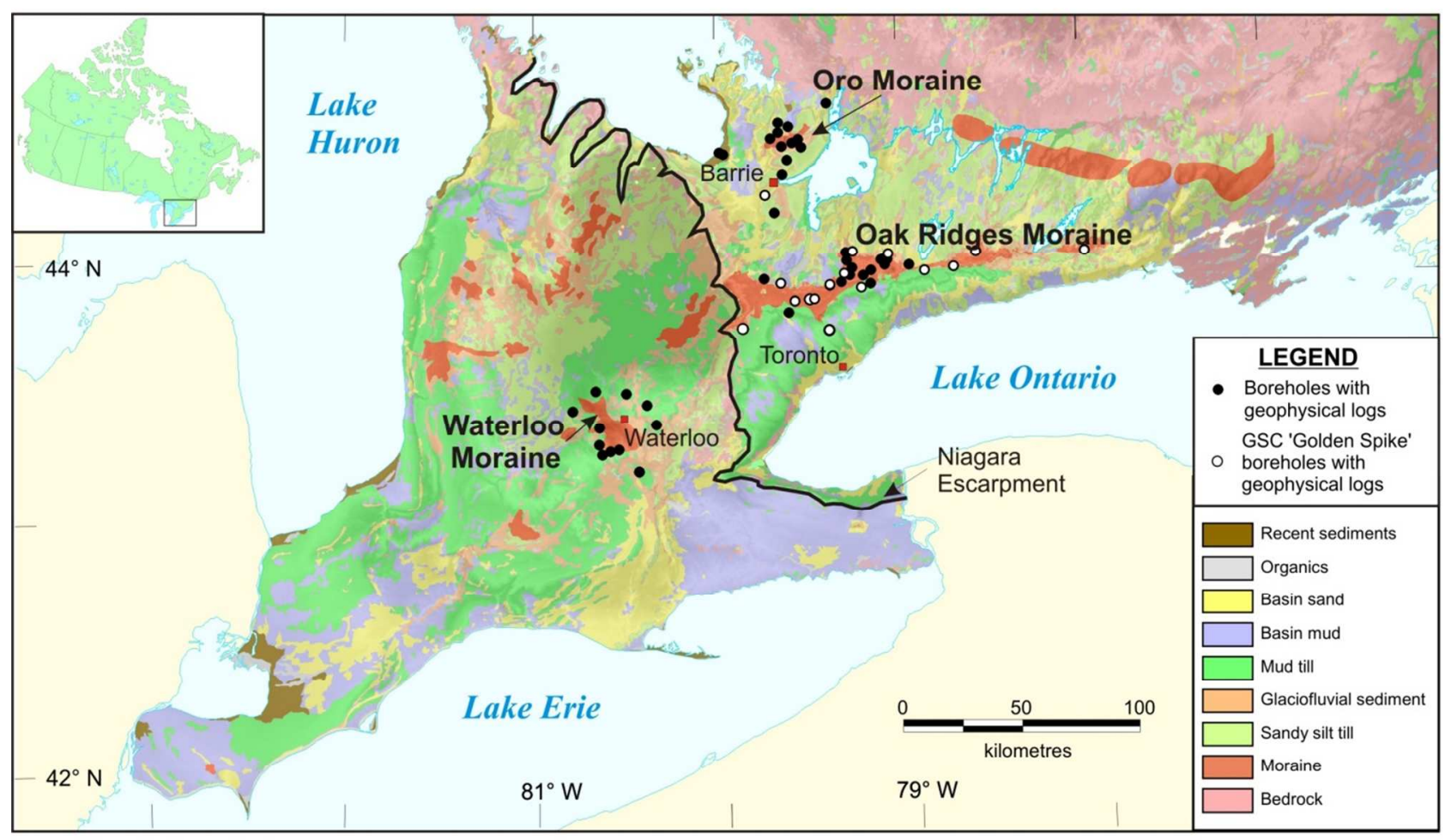

2 Figure 1 - Location map and general surficial geology of Southern Ontario, modified from

3 Barnett et al (1991). Locations are plotted of sediment boreholes geophysically logged by the

4 Geological Survey of Canada between $1993-2013$. 
Precambrian Altered Granite, open hole

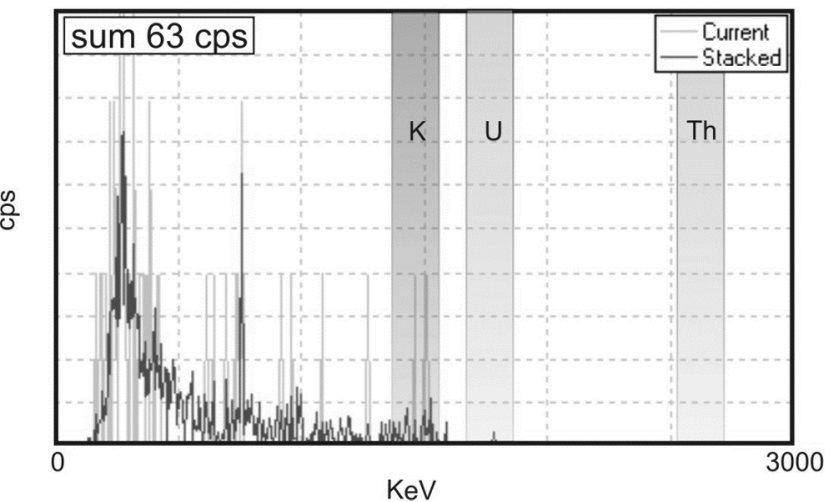

Glacial Sediment, PVC-cased borehole

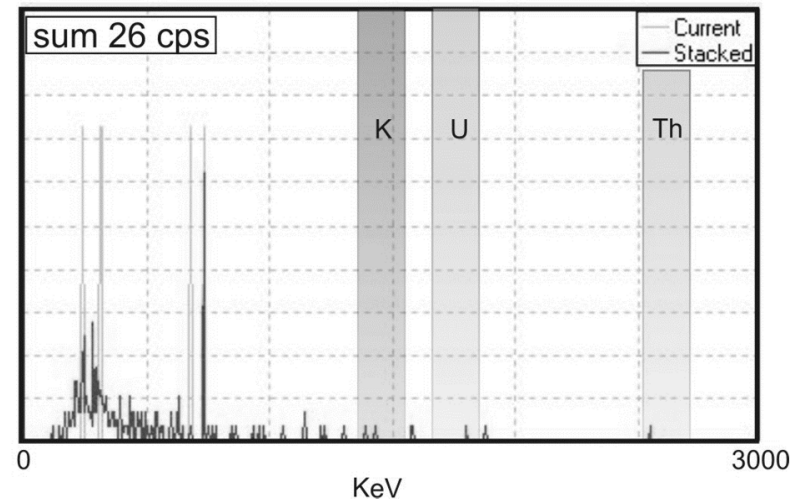

7 Figure 2 - Comparison of gamma energy spectrums (kiloelectron volts, keV) plotted against counts per second (cps) from an open bedrock borehole (left) and a PVC-cased glacial sediment (right). On the left, the record was collected at the GSC's Ottawa ON borehole calibration facility in an interval of Grenville-age altered granite consisting of friable clays and altered feldspars derived from syenites, granites, and gneisses. On the right, the record was collected in glacial sediment within the Thorncliffe Formation (clay- and silt-sized particles) of the Lower Sediment unit near Oshawa, ON. The red trace indicates a stacked spectrum summed $10 \mathrm{~cm}$ above and below the sensor depth. Although from different regions of Ontario, this comparison, collected by the same spectral tool moving at $1 \mathrm{~m} / \mathrm{min}$, illustrates the reduction in spectral amplitudes and count levels recorded in a fine grained glacial sediment of southern ON versus an open bedrock borehole in eastern ON. 


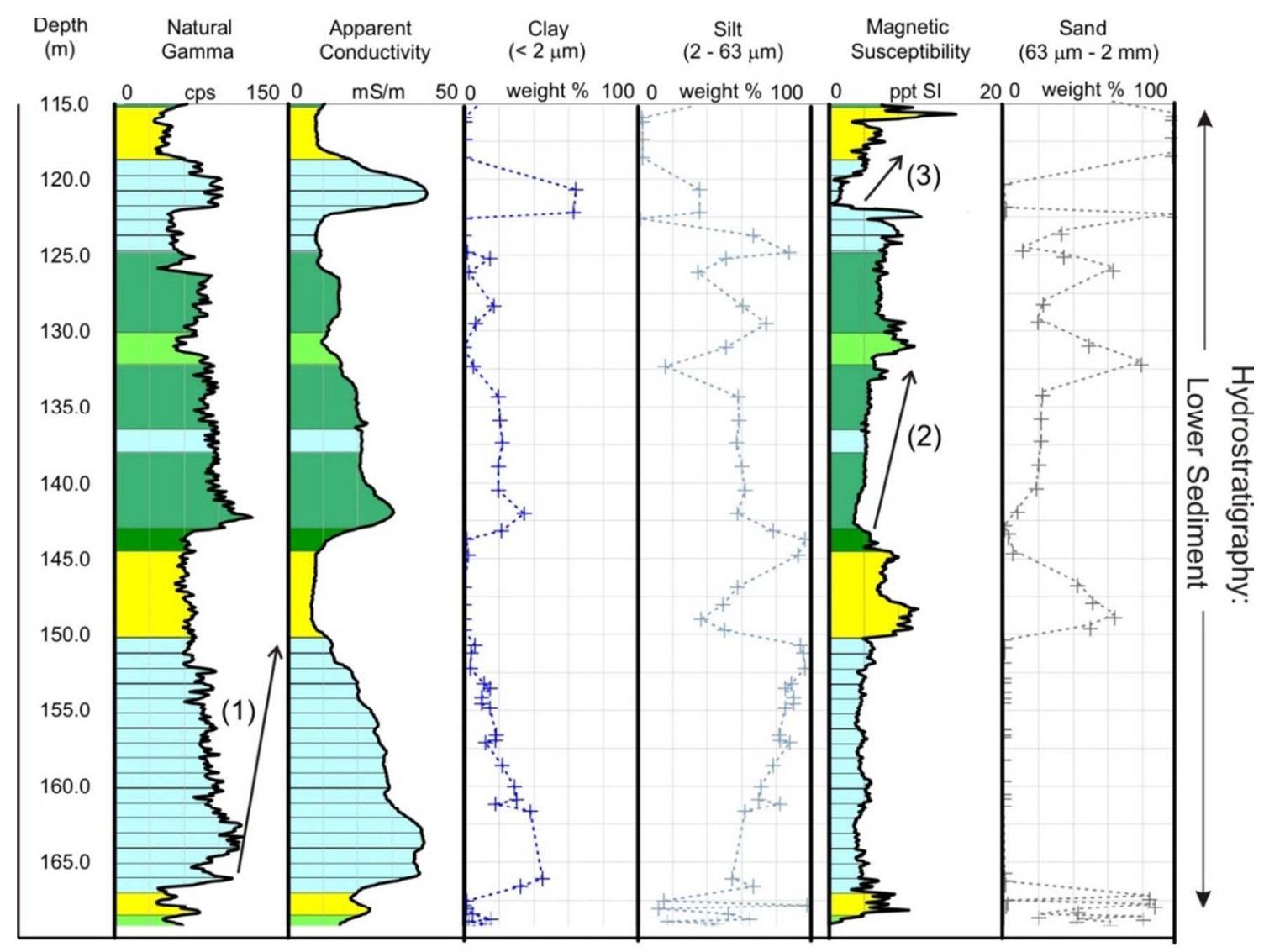

Simplified material descriptions

Silt and clay

Silt

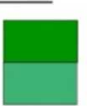

Diamicton
silty/clayey
clayey/silty/sandy

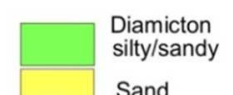

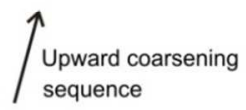

Sand
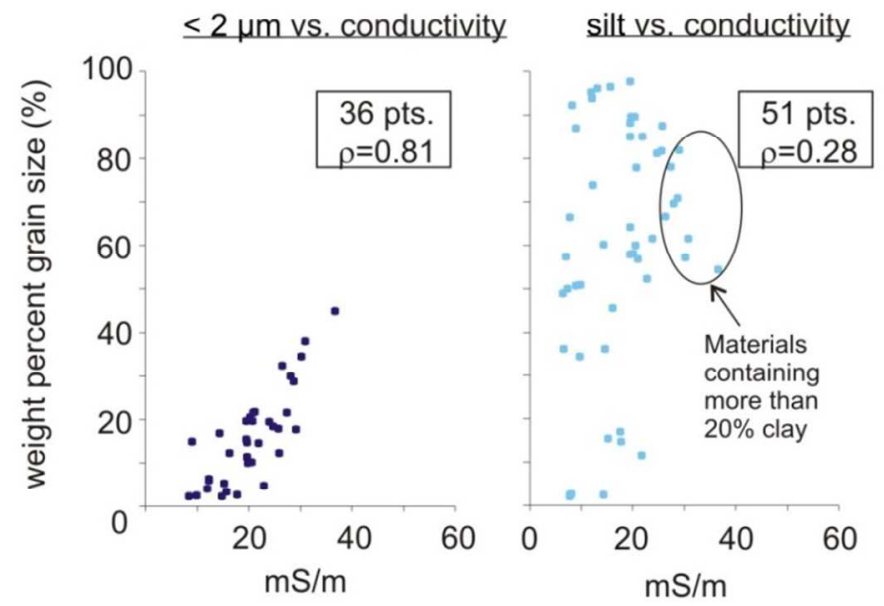

sand vs. mag. susc.

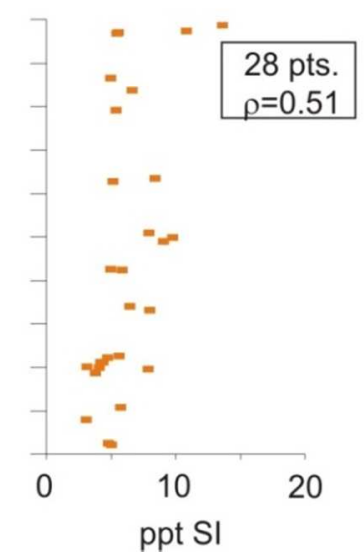

Figure 3 - Geophysical logs (gamma, conductivity, and magnetic susceptibility) from the eastern

22 GTA region, north of Clarington ON (PP02-1), plotted alongside grain size data and sediment 
23 descriptions from continuous core in the Lower Sediment hydrostratigraphic unit. The 24 geophysical log responses primarily reflect the changing clay content (gamma, conductivity) and 25 sand content (magnetic susceptibility) as shown in the cross plots. Three different upward 26 coarsening trends are identified based on changing grain sizes: (1) decrease in clay, increase in 27 silt, no change in sand in upward coarsening rhythmites; (2) decrease in clay, no change in silt, 28 increase in sand; (3) decrease in clay, decrease in silt, increase in sand in upward coarsening 29 rhythmites. Sediment descriptions based on Russell et al. (2003b).

30 

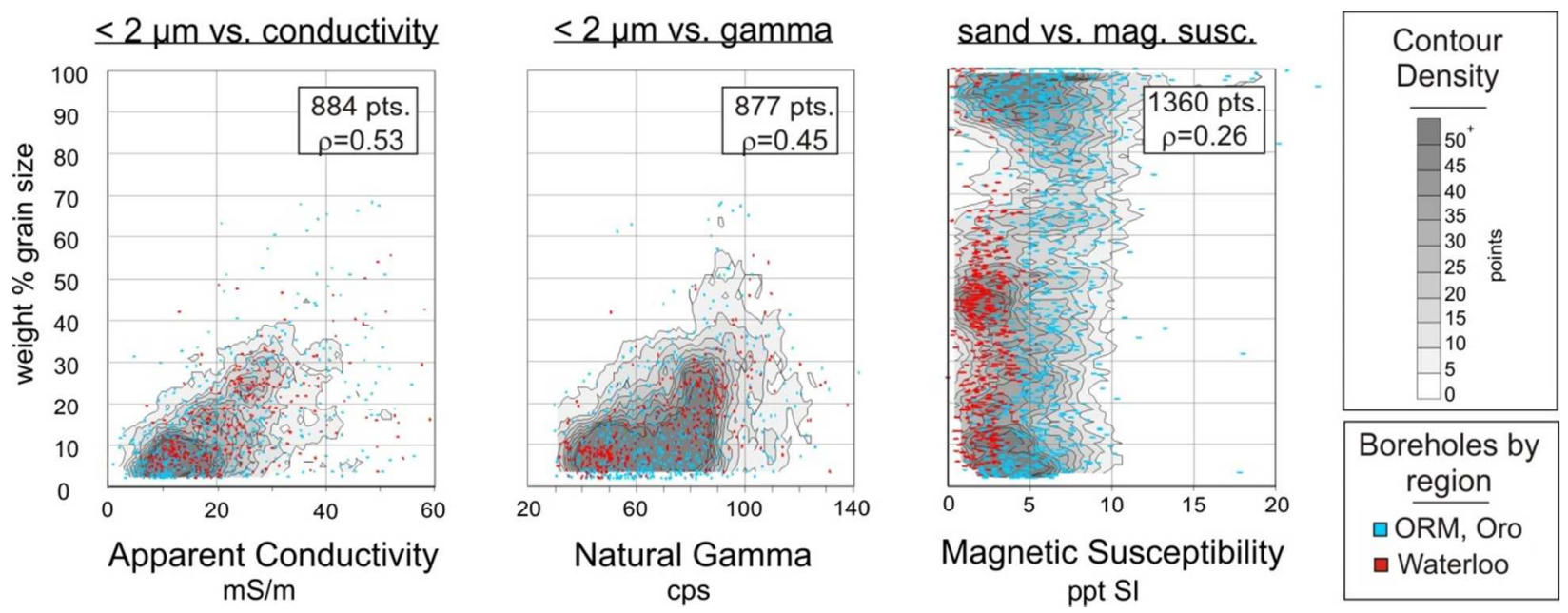

Figure 4 - Selected contoured cross plots of grain size versus geophysical log response indicate that despite scatter, trends are present across the study region, with the strongest influence on conductivity and gamma coming from the presence of the $<2$ micron $(\mu \mathrm{m})$ size fraction. Sediments from the Waterloo region west of the Niagara escarpment systematically show lower magnetic susceptibilities in sands (also in silt and clay, not shown), and often, higher conductivities and gamma responses in clays versus those east of the Escarpment. Data from 28 boreholes: 9 in the Waterloo region (west of the Niagara Escarpment); 11 from Oro and 8 from the GTA (east of the Niagara Escarpment). 

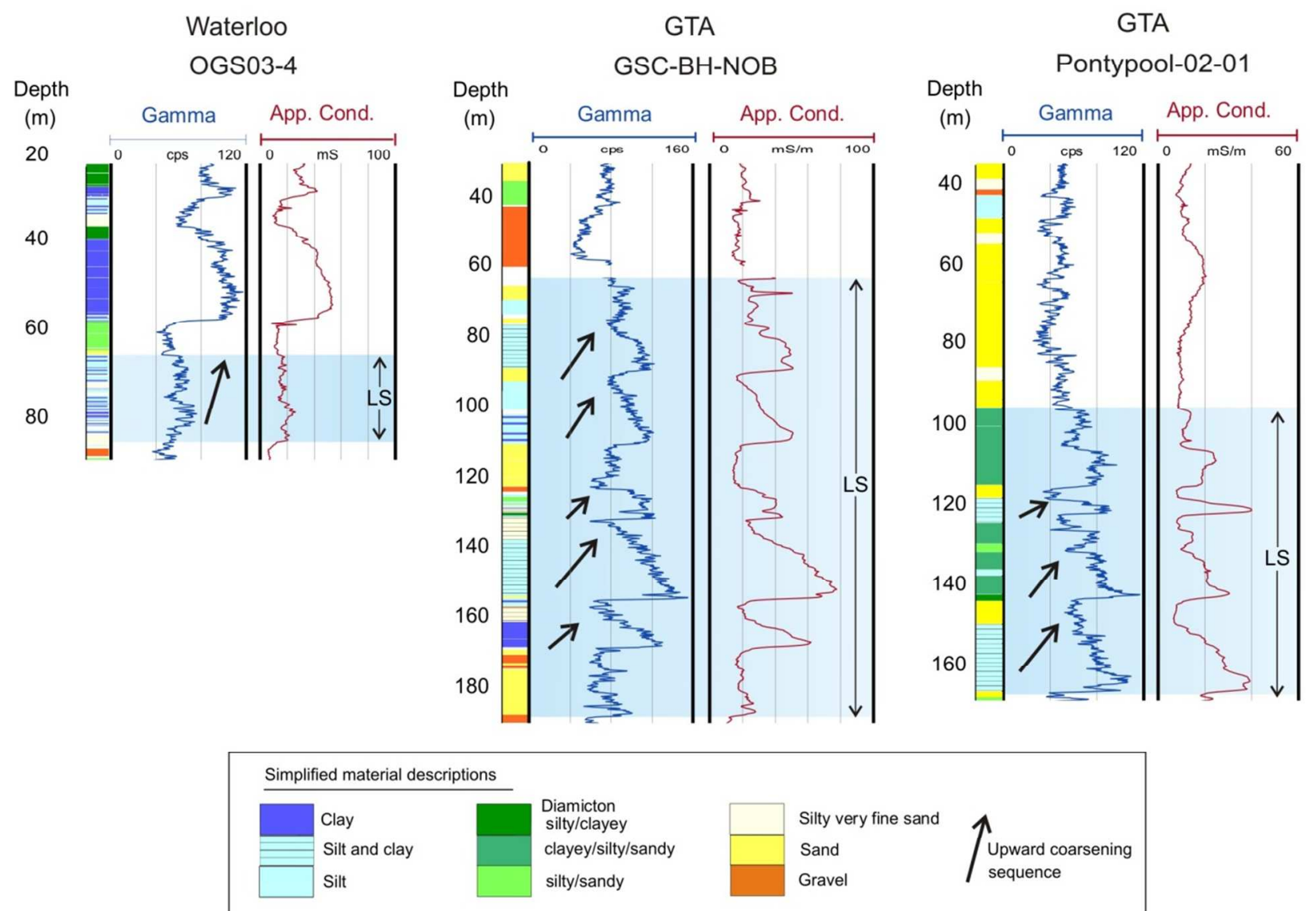

Figure 5 - Sample logs exhibiting the funnel pattern characteristic of upward coarsening rhythmite sequences in the lower sediment (blue intervals). Sediment descriptions from Bajc and Hunter (2006); Logan et al. (2008), and Russell et al. (2004). 

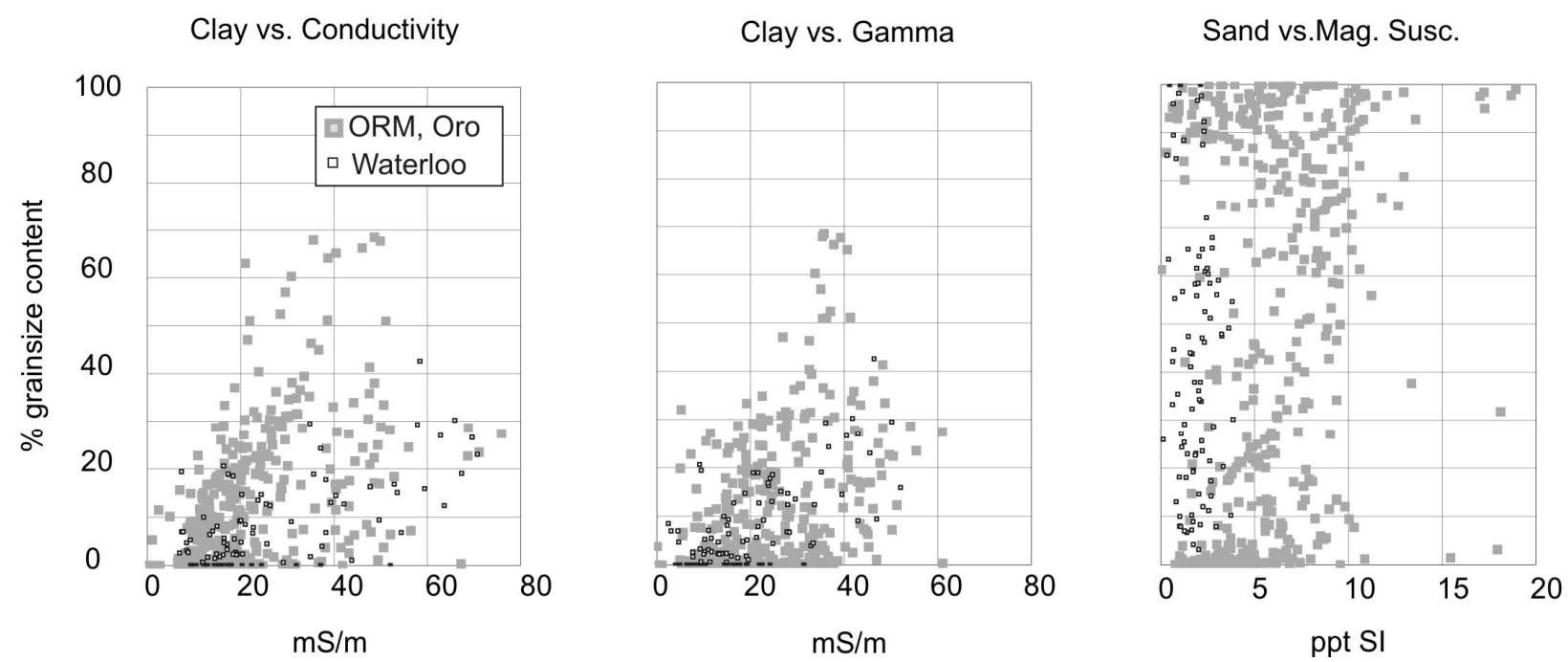

49 Figure 6 - Plots of grainsize versus log response show a significant degree of scatter, as this unit 50 is composed of alternating glaciolacustrine formations and diamictons containing a range of 51 grain sizes. Plots highlight differences in log response between the regions east and west of the

52 Niagara Escarpment; in particular, the lower magnetic susceptibilities in the sands. (Waterloo: 7

53 boreholes; GTA: 5 boreholes; Oro: 9 boreholes), 
Waterloo - Catfish Creek Till

OGS03-7

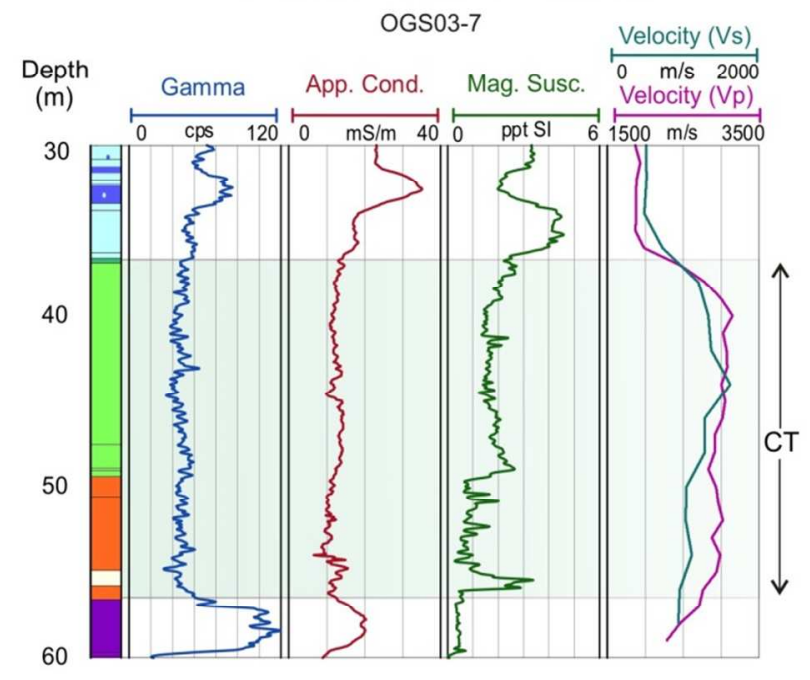

56

60

61

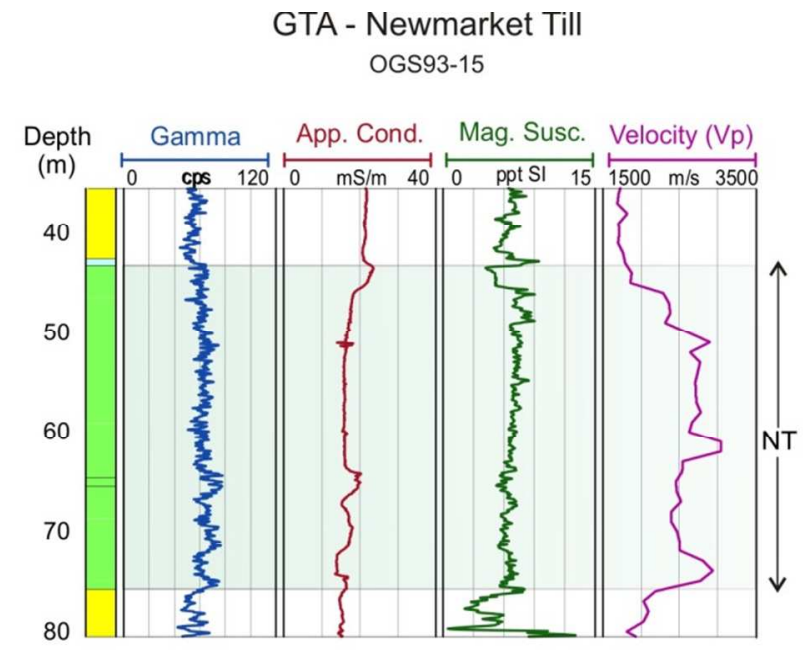

GTA - Newmarket Till

GLL-02

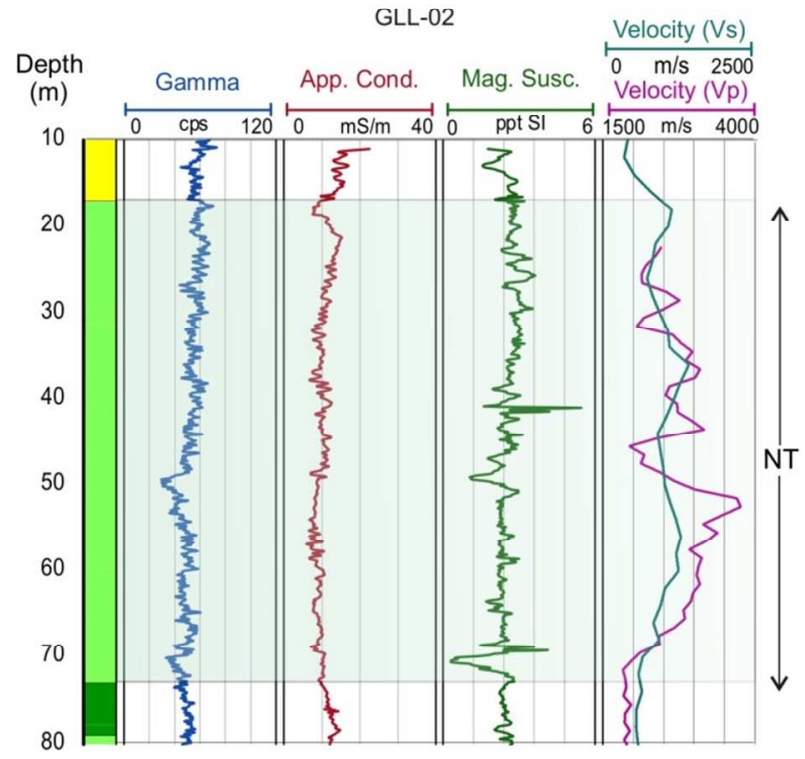

Figure 7 - Sample logs showing elevated velocities within the Newmarket and Catfish Creek tills (light green intervals), but relatively low and unvarying lithological log responses. Sediment descriptions from Bajc and Hunter (2006), and Crow et al. (2015a). 


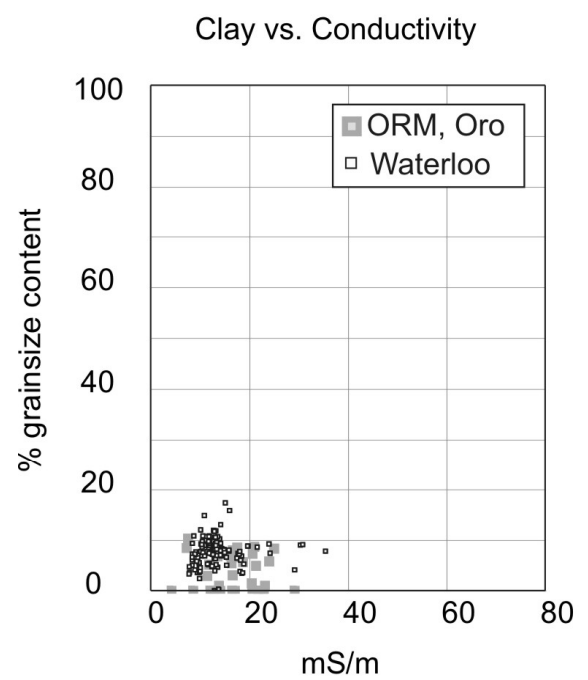

Figure 8 - In the high velocity tills, clusters in the grain size versus log response plots reflect a

64 relative uniformity in the matrix grain size, particularly in the Waterloo region (8 boreholes). In

65

66

67

68

69
Silt vs. Conductivity

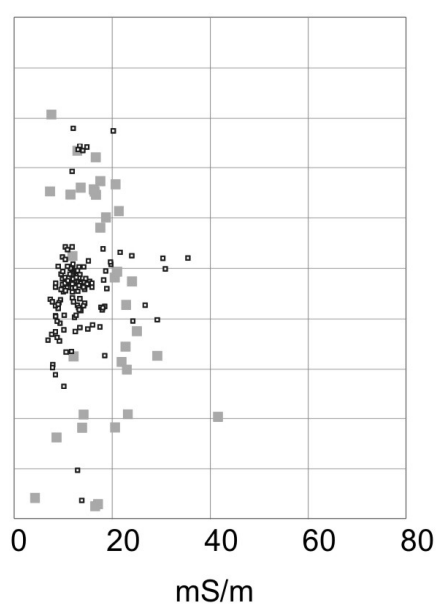

Sand vs.Mag. Susc.

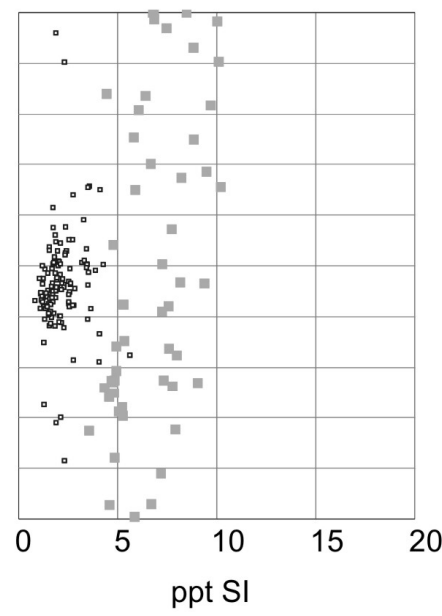
the Oro area ( 7 boreholes), the magnetic susceptibility is more elevated and sand content more variable. Little Newmarket Till grain size data is available in logged boreholes in the GTA (1 borehole). Conductivity (and gamma, not shown) remains relatively low due to little $<2$ micron grain size content. 

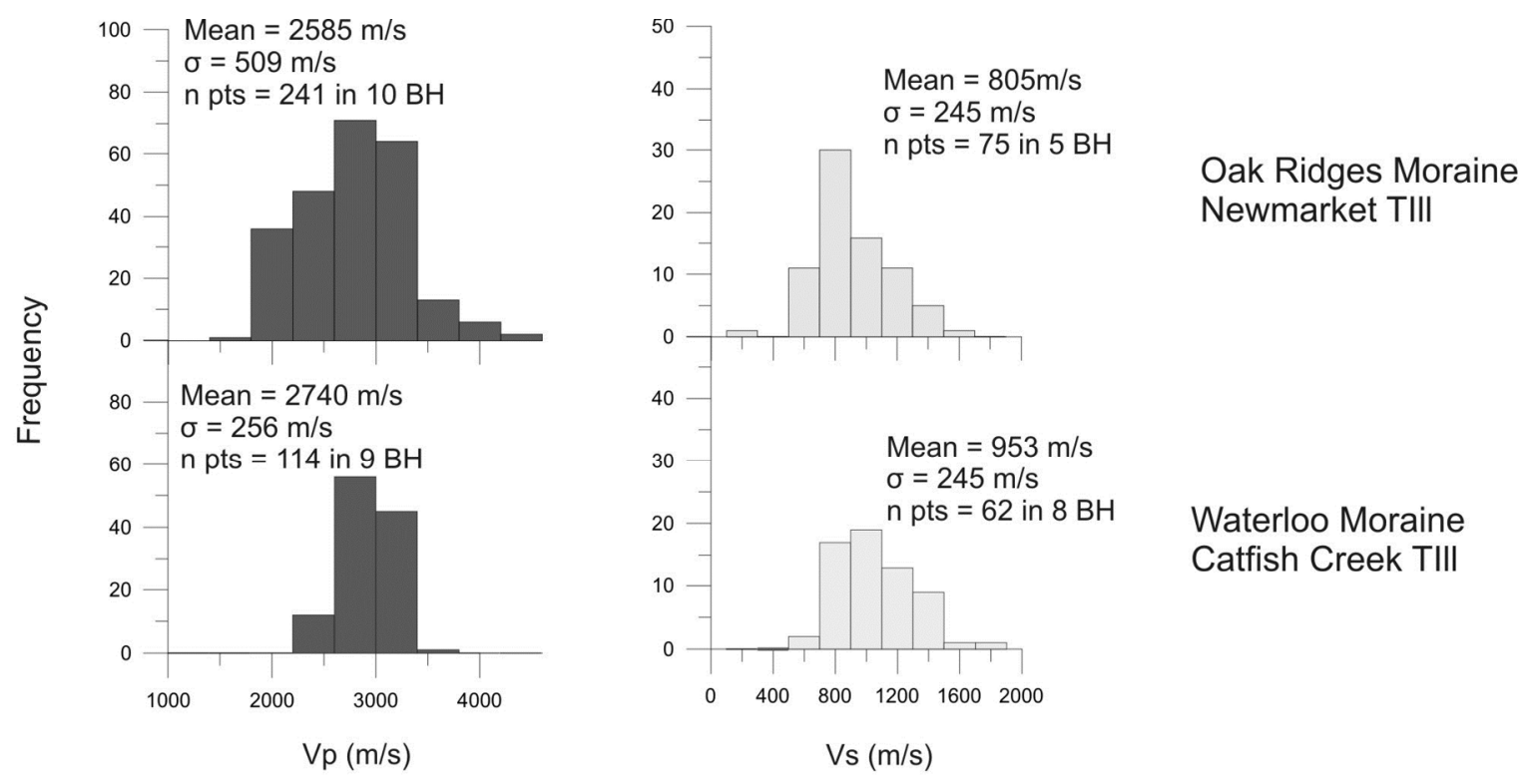

71 Figure 9 - Comparison of the distributions of $\mathrm{Vp}$ and $\mathrm{Vs}$ in the Newmarket and the Catfish 72 Creek tills. 


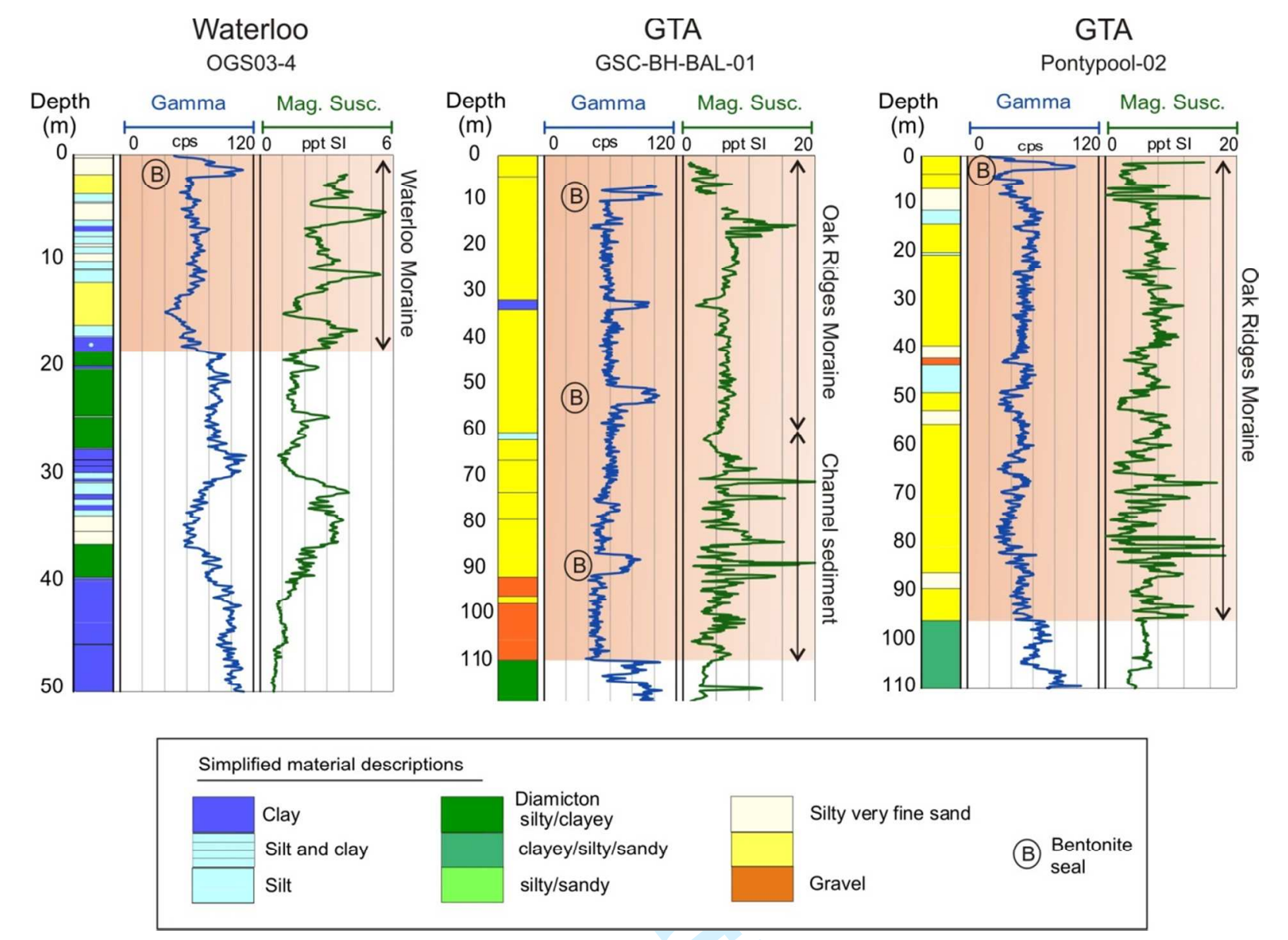

75

Figure 10 - Sample logs with characteristic responses in the moraine sediments (orange

76 intervals). Gamma counts tend to remain low and unvarying due to limited clay content, while

77 magnetic susceptibility is elevated and highly varying. Sediment descriptions from Bajc and

78 Hunter (2006); Sharpe et al. (2003), and Russell et al. (2004). 

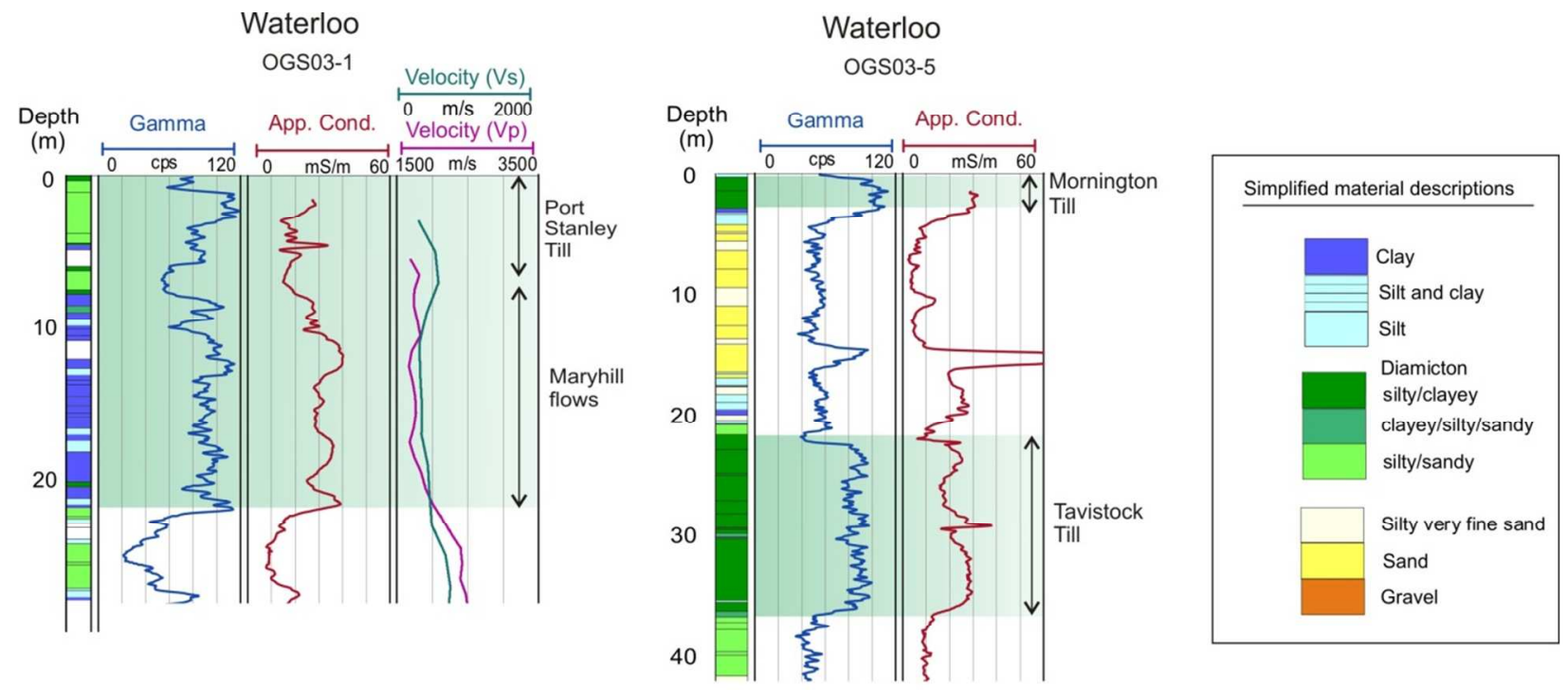

81

Figure 11 - Sample logs indicating the elevated response of the gamma and conductivity logs,

83 and reduced velocities, in the surficial tills (green intervals). Sediment descriptions from Bajc and Hunter (2006); assignment of stratigraphy in Waterloo region from Bajc and Shirota (2007). 

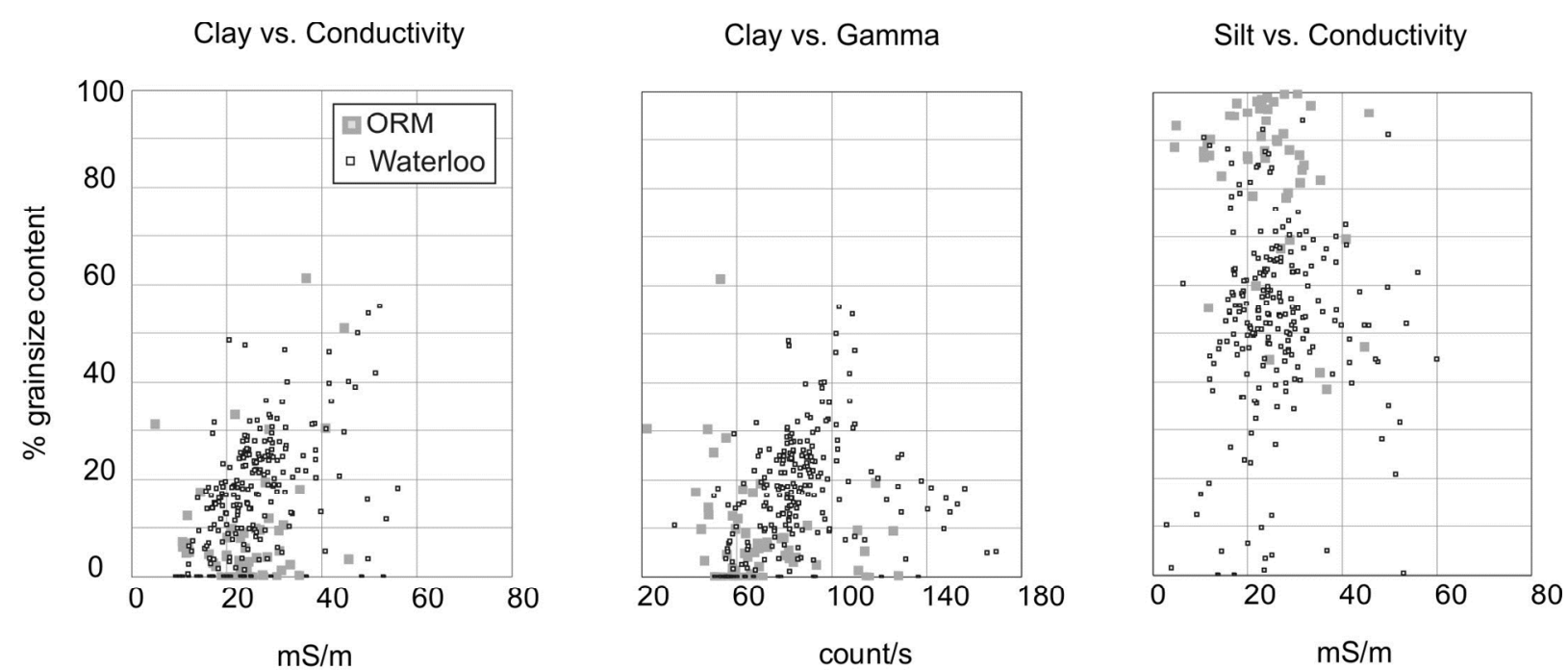

85

86

87

88

89

90

Figure 12 - Log response versus grainsize percentage in the surficial silty-clay and clayey-silt tills across southern Ontario. The presence of $<2$ micron grain size particles, even in quantities $<40 \%$, has a stronger influence on the gamma and conductivity response than the other grain sizes. Plots contain data from the GTA (4 boreholes) and Waterloo ( 9 boreholes). 
A)

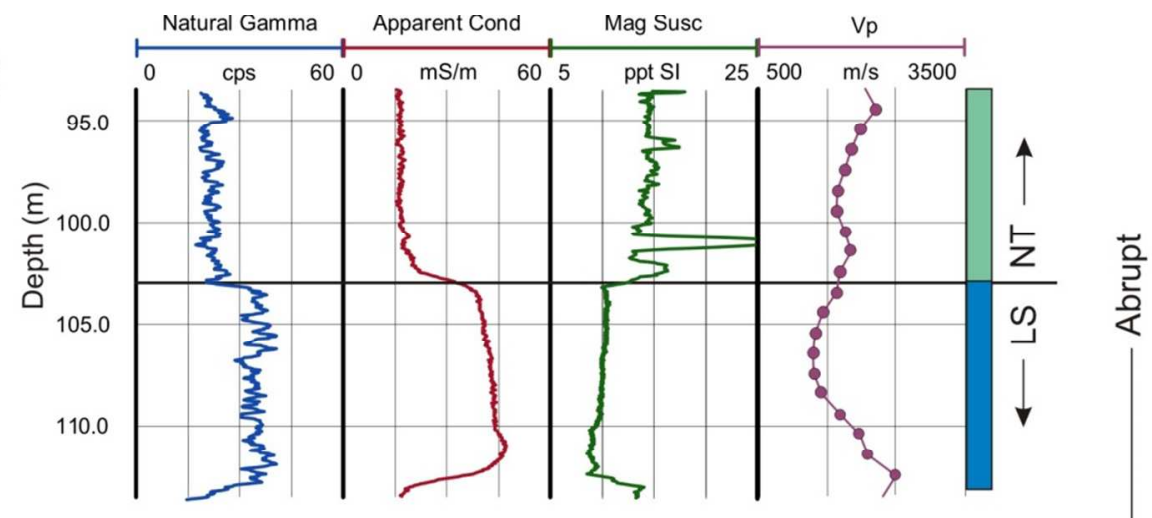

B)

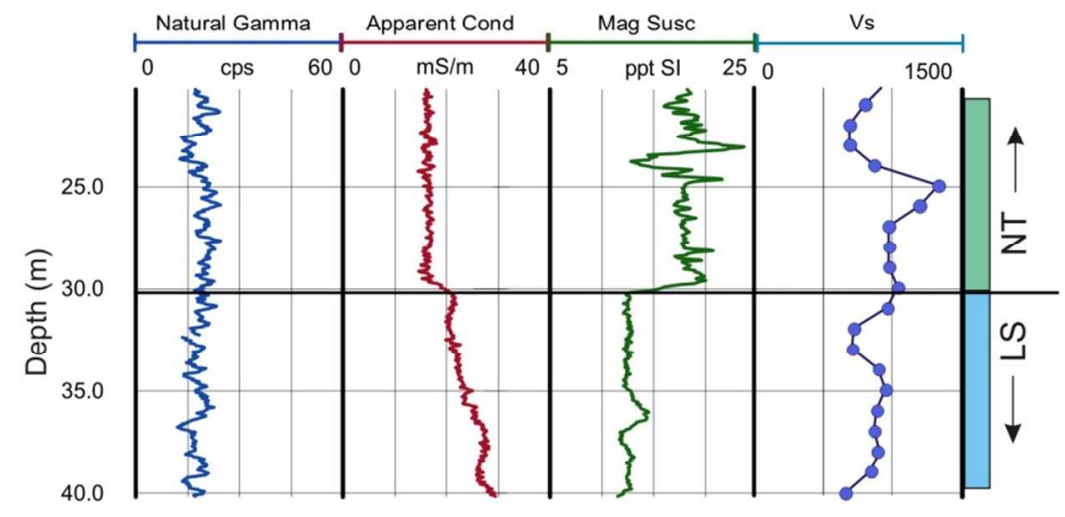

C)
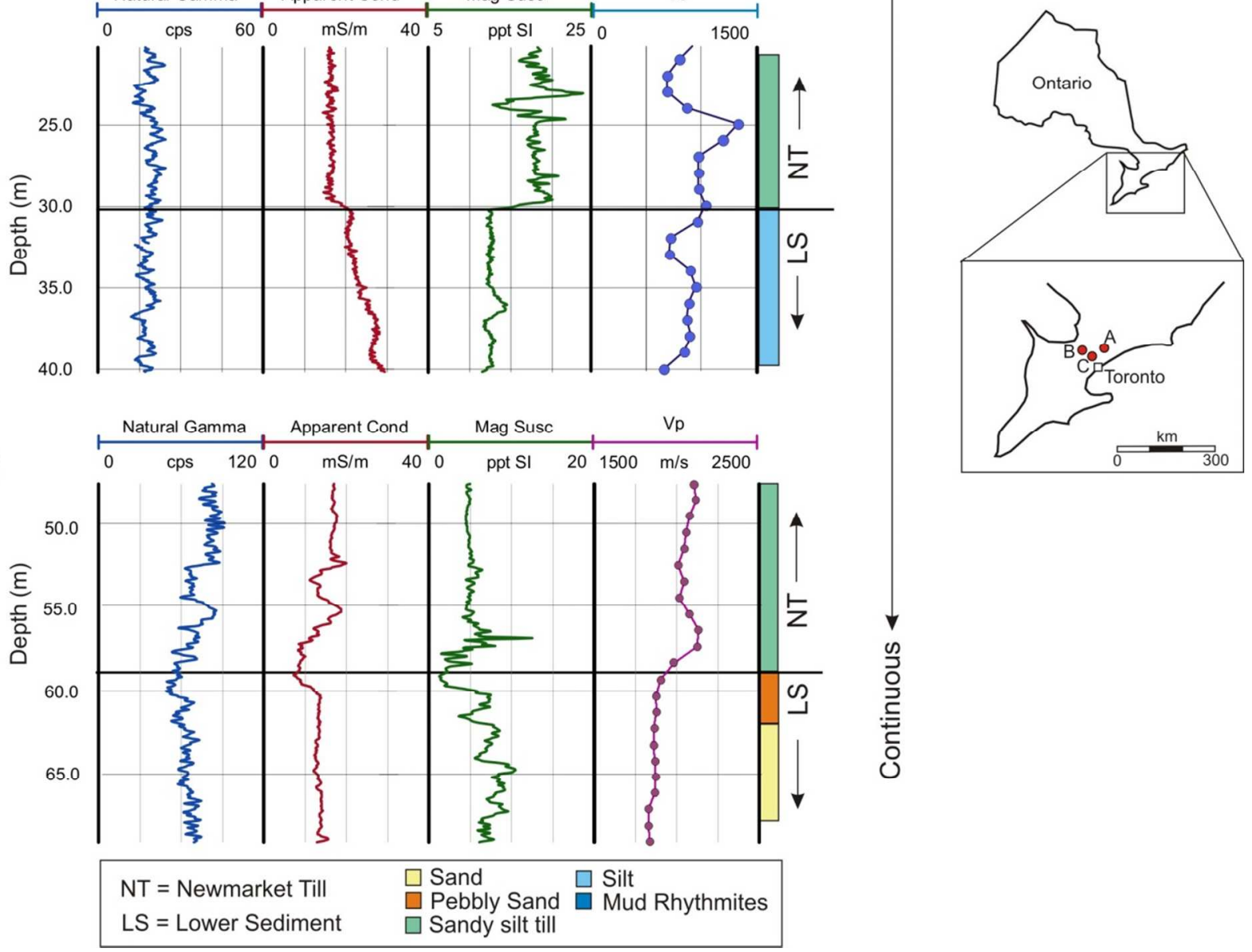

Figure 13 - Variability in log response at the stratigraphic boundary between Newmarket Till and Lower Sediments (i.e. abrupt vs continuous) can assist in the interpretation of glacial processes. In (A) all logs indicate a sharp transition while in (B), the induction logs are sharp but with less contrast. In (C), logs show little variation across the contact save for the increase in velocity. Sediment descriptions from Coffin et al. (2017), Bajc et al. (2015), Logan et al. (2008). 


\section{Borehole geophysical log signatures and stratigraphic assessment in a glacial basin, southern Ontario; Crow et al.}

\section{Tables}

Table 1 - simplified sediment character within stratigraphic units and formation nomenclature across the region. $\mathrm{Fm}=$ formation.

\begin{tabular}{|c|c|c|c|c|}
\hline \multirow{2}{*}{$\begin{array}{l}\text { Stratigraphic } \\
\text { Unit }\end{array}$} & \multirow{2}{*}{$\begin{array}{c}\text { Generalized sediment } \\
\text { character }\end{array}$} & \multicolumn{3}{|c|}{ Formation Nomenclature } \\
\hline & & GTA & Oro & Waterloo \\
\hline Surficial tills & $\begin{array}{l}\text { Several late glacial tills. } \\
\text { Interbedded clayey-silt, } \\
\text { silty-clay with sand and } \\
\text { gravel and silty to sandy } \\
\text { diamictons. }\end{array}$ & $\begin{array}{l}\text { Kettleby and } \\
\text { Wentworth } \\
\text { Tills, Halton } \\
\text { sediments }\end{array}$ & $\begin{array}{l}\text { None } \\
\text { identified }\end{array}$ & $\begin{array}{l}\text { Maryhill, } \\
\text { Mornington, Port } \\
\text { Stanley, } \\
\text { Tavistock, } \\
\text { Wentworth tills } \\
\end{array}$ \\
\hline $\begin{array}{l}\text { Moraine and } \\
\text { channel } \\
\text { sediment }\end{array}$ & $\begin{array}{l}\text { Moraine: extensive stratified } \\
\text { complexes, interbedded fine } \\
\text { sands and silts with sands } \\
\text { and gravels, fining upward } \\
\text { successions are common } \\
\text { Channels: cut into } \\
\text { underlying sediments, } \\
\text { contain sandy sediments, } \\
\text { some contain cross-bedded } \\
\text { gravels, often overlain by } \\
\text { mud intervals. }\end{array}$ & $\begin{array}{l}\text { Oak Ridges } \\
\text { Moraine }\end{array}$ & Oro Moraine & $\begin{array}{l}\text { Waterloo } \\
\text { Moraine }\end{array}$ \\
\hline $\begin{array}{l}\text { High velocity } \\
\text { tills }\end{array}$ & $\begin{array}{l}\text { Dense, stony, sandy silt } \\
\text { diamicton, with distinct } \\
\text { clay/silt, sand, and } \\
\text { gravel/stony interbeds. }\end{array}$ & \multicolumn{2}{|l|}{ Newmarket Till } & Catfish Creek Till \\
\hline Lower sediment & $\begin{array}{l}\text { Group of up to } 10 \\
\text { formations and tills of } \\
\text { Illinoian to mid- } \\
\text { Wisconsinan age. Gravel, } \\
\text { sand, silt, clay, and tills, } \\
\text { and distinctive } \\
\text { organic/fossil-bearing beds. } \\
\text { Fine-grained sediments can } \\
\text { be massive to laminated. }\end{array}$ & $\begin{array}{l}\text { Thorncliffe } \\
\text { Fm, } \\
\text { Meadowcliffe, } \\
\text { Seminary and } \\
\text { Sunnybrook } \\
\text { tills, Pottery } \\
\text { Road Fm, } \\
\text { Scarborough } \\
\text { Fm, Don Fm, } \\
\text { and York Till }\end{array}$ & $\begin{array}{l}\text { Thorncliffe } \\
\text { Fm, } \\
\text { Sunnybrook } \\
\text { and York tills, } \\
\text { Scarborough } \\
\text { Fm. }\end{array}$ & $\begin{array}{l}\text { pre-Catfish } \\
\text { sediment, } \\
\text { Canning Till, } \\
\text { Pre-Canning } \\
\text { sediment }\end{array}$ \\
\hline Bedrock & Sedimentary bedrock & \multicolumn{2}{|c|}{$\begin{array}{l}\text { Upper and Middle Ordovician } \\
\text { limestone, dolostone, siltstone, } \\
\text { shale }\end{array}$} & $\begin{array}{l}\text { Silurian } \\
\text { limestone, } \\
\text { dolostone, } \\
\text { siltstone, shale, } \\
\text { sandstone, } \\
\text { gypsum }\end{array}$ \\
\hline
\end{tabular}


Table 2 - Velocity distributions within the hydrostratigraphic units. Data are presented \pm one (1) standard deviation. Number of depth records provided for each calculation.

\begin{tabular}{|c|c|c|c|c|}
\hline & Surficial tills & $\begin{array}{c}\text { Moraine and } \\
\text { channel deposits }\end{array}$ & High velocity tills & Lower sediments \\
\hline $\mathrm{Vp}(\mathrm{m} / \mathrm{s})$ & $\begin{array}{c}1855 \pm 235 \\
\mathrm{n}^{\mathrm{o}}=365\end{array}$ & $\begin{array}{c}1875 \pm 350 \\
\mathrm{n}^{\mathrm{o}}=765\end{array}$ & $\begin{array}{c}2610 \pm 475 \\
\mathrm{n}^{\circ}=366\end{array}$ & $\begin{array}{c}2075 \pm 360 \\
\mathrm{n}^{\mathrm{o}}=1874\end{array}$ \\
\hline $\mathrm{Vs}(\mathrm{m} / \mathrm{s})$ & $\begin{array}{c}465 \pm 145 \\
\mathrm{n}^{\mathrm{o}}=355\end{array}$ & $\begin{array}{c}540 \pm 165 \\
\mathrm{n}^{\mathrm{o}}=366\end{array}$ & $\begin{array}{c}845 \pm 255 \\
\mathrm{n}^{\circ}=154\end{array}$ & $\begin{array}{c}715 \pm 205 \\
\mathrm{n}^{\circ}=851\end{array}$ \\
\hline $\mathrm{Vp}:$ Vs ratio & $\begin{array}{c}4.01 \pm 0.86 \\
\mathrm{n}^{\mathrm{o}}=287\end{array}$ & $\begin{array}{c}3.50 \pm 0.74 \\
\mathrm{n}^{\mathrm{o}}=262\end{array}$ & $\begin{array}{c}2.87 \pm 0.53 \\
\mathrm{n}^{\circ}=154\end{array}$ & $\begin{array}{c}3.03 \pm 0.57 \\
\mathrm{n}^{\circ}=696\end{array}$ \\
\hline
\end{tabular}

